\title{
BOKOR Attila
}

\section{LÉTEZIK-E ITTHON Y-GENERÁCIÓ?}

A Budapesti Corvinus Egyetem Vezetéstudományi Intézete és az OD Partner Kft. közös kutatócsapata 2005ben indította el a „Karriermenedzsment Magyarországon” címú átfogó kutatási programját. A teljes kutatási anyag feldolgozása még folyik, jelen tanulmány csupán a pályakezdók karrierképére irányuló elemzéseket foglalja össze, azon belül is elsôsorban a karrierkép és a generációs önkép témáira fókuszálva. Azt vizsgálja, hogy a pályakezdók karrierelképzelései alapján meghatározható-e Magyarországon egy külön generáció.

\section{Kiindulási pontok ${ }^{1}$}

A hazai szakirodalomban kevés példa vált ismertté, amelyen keresztül megérthetnénk, hogy a hazai üzleti és kulturális sajátosságok fényében milyen akadályok és lehetôségek befolyásolják a nemzetközi szakirodalomban, illetve a hazai és külföldi HR-gyakorlatban is nagy figyelmet kapott karrier és karriermenedzsment témakört. ${ }^{1}$

A karrierhez köthetố kérdések mind az egyén, mind pedig a tágabb környezet szintjén számos izgalmas kérdést vetnek fel elméleti és gyakorlati szempontból egyaránt. Grandjean (1981: 1057, idézi Mayrhofer et al. 2006) megfogalmazása szerint a téma a „társadalmi történelem és az egyéni életút közös határmezsgyéjén található", azaz a mikro- és a makroszintú keretek öszszekapcsolódását jelenti. A személyes siker, a státus, a különbözố nemek és társadalmi csoportok eltérô lehetôségei, a mobilitás vagy az elérhetô karrierutak az egyének és szervezetek számára egyaránt fontos kérdések, és általánosabb társadalomtudományi dilemmákat, a jelen kontextus mélyebb megértésének lehetôségét is felvetik. Így feltehetjük, vajon a jelen tanulmányban vizsgált korosztály karrierképe egyben általánosabb társadalmi folyamatok feltárására is lehetôséget ad?

A karrier koncepciója azért is izgalmas, mert a szakirodalomban egyre inkább elótérbe kerül a „szubjektív karrier" fogalma (Gattiker - Larwood, 1988). E fogalmon keresztül az egyének meg tudják ragadni, és értelemteli egészbe képesek rendezni az életüket formáló különféle hatásokat. Manapság Rose (1989) szerint az „én” egy olyan önirányító entitásnak képzelhetố el, aki a munkában és azon kívül is autonóm individuumként próbálja meg formálni életét, elsősorban az önmegvalósítás motivációjának engedelmeskedve. A karrier az identitás megalkotásának a terepe, a karrierhez való viszonyon keresztül pedig az egyén és a társadalmi közeg egymásra hatása megérthetô.

A Budapesti Corvinus Egyetem Vezetéstudományi Intézete és az OD Partner Kft. közös kutatócsapata minderre alapozva indította el 2005-ben a „Karriermenedzsment Magyarországon" címú átfogó kutatási programját. ${ }^{2}$ Feltáró célú kutatásunkkal a következő részterületeken végzett elemzésekkel vizsgáltuk a témakör hazai sajátosságait:

1. HR-vezetói interjúk: a HR-terület céljainak, szerepének megértése, valamint az alkalmazott gyakorlatok megismerése. (51 interjú)

2. Online kérdőív: a tehetségek karriermotivációinak, elvárásainak és a karriermenedzsment-tevékenységekkel való elégedettségének a felmérésére. (kb. 1000 kitöltött kérdőív)

3. Fókuszcsoportok az Y-generáció képviselôivel: a munkaerópiacra mostanában kilépó korosztály sajátos jellemzóinek a megértése. (19 fókuszcsoport)

A teljes kutatási anyag feldolgozása még folyik, jelen tanulmány csupán a pályakezdốk karrierképére irányuló elemzéseket foglalja össze tartalmazza, azon belül is elsősorban a karrierkép és a generációs önkép témáira fókuszálva.

\section{A korosztályos kutatás általános céljai és módszertana}

E kutatási alprojekt kiinduló pontjait egyfelól azok a szakirodalmi elemzések jelentették, amelyek azt állítják, hogy a fejlett nyugati országokban az elmúlt években egy újfajta értékrenddel és elvárásokkal rendelkezó korosztály - Y-generáció - lépett ki a munkaerópiacra. 
Másfelól pedig több hazai HR-vezetôvel elôzetesen egyeztetve felmerült az a dilemma, hogy problémákat érzékelnek az elmúlt években végzettek toborzását, motiválását és megtartását illetôen. Természetesen adódott a kérdés, hogy lehetséges-e kapcsolat a két kiindulópont között. Így két szinten is megfogalmazhatók a céljaink. Elméleti szinten: Igaz-e az a megállítás, hogy egy új generáció lépett ki a munkaerópiacra? Gyakorlati szinten: mi okozza a fiatal munkavállalók beilleszkedésének és karrierkezdésének problémáit, és milyen eszközökkel lehetséges a munkaadói és a munkavállalói oldal számára a legmegfelelóbb keretek kialakítása?

A kérdések megválaszolása érdekében szándékunk az volt, hogy megismerjük a végzéshez közel állók, valamint egy-két éve dolgozó fiatalok elképzeléseit, gondolatait, elvárásait, és mindezt összevethessük lehetôségeinknek megfelelően más elemzési módszerek - például a kérdôívezés - során kapott eredményekkel. Részletesebben megfogalmazva ez a következóket jelentette:

- Megismerni a fiatal pályakezdők korosztályos önképét, az egyének önértékelését, és egyben megvizsgálni: vajon ôk-e a szakirodalomban említett Y-generáció.

- Megismerni a fiatal pályakezdók karrierrel kapcsolatos vágyait, céljait és tapasztalatait.

- Megtudni, hogy milyen lépéseket tesznek diákéveik alatt és közvetlenül azután a karrierépítésük megalapozása érdekében.

- Információt kapni arról, milyen szempontok és befolyások alapján választják munkahelyüket.

- Megtudni, hogy milyen elvárásaik vannak a vállalatokkal, a HR-rel, saját magukkal és a fónökükkel szemben.

- Képet kapni arról, hogy miben különböznek, és miben hasonlítanak az idősebb korosztályokhoz képest.

A kutatás során két módszertant alkalmaztunk. Egyrészt kvalitatív módszertannal, fókuszcsoportos beszélgetések során igyekeztünk megismerni ezt a korosztályt. Célunk a generációs önkép kutatása volt, így alkalmasnak véltük a módszertant, hiszen a félig strukturált módon folyó csoportmegbeszélés jó betekintést adhat számunkra, és a személyes kapcsolat lehetôséget nyújtott ellenőrzố, mélyítő és provokatív kérdések feltételére is.

Egy rövid kérdő́ivvel pedig képet kaphattunk a mintában szereplő́k elvárásairól, önképéról. A kérdések kialakításakor ügyeltünk arra, hogy némely kérdések esetén összehasonlítható legyen a korábban elvégzett stakeholder-analízissel. (A kutatás online kérdőíves felmérése, a késóbbiekben SHA.) Mivel a fókuszcsoportos beszélgetés előtt 10 perc állt rendelkezésre a kérdőív kitöltésére, ügyeltünk annak rövidségére, egyszerúségére.
A csoportmegbeszéléseken elhangzottakat magnóra rögzítés után, vagy pedig rögtön a helyszínen begépeltettük. A jegyzókönyveket az NVivo 7.0 kvalitatív szövegelemzó szoftver segítségével kódoltuk, majd a kialakult kódok és kategóriák alapján elemeztük.

A kutatás során a részt vevő egyéneknek olyan formán biztosítjuk az anonimitást, hogy az idézetek és elemzések során nem tesszük felismerhetôvé, hogy mely konkrét információk mely egyéntól, valamint mely szervezetnél lefolytatott fókuszcsoport beszélgetéséból származnak. (Az idézetek esetében számmal tesszük követhetôvé, hogy mely idézetek származnak azonos fókuszcsoportoktól.)

Mintavételi kérdések két szinten is felmerültek a kutatás során: mely szervezetekben és milyen pályakezdốk vegyenek részt a kutatásban. Elsôsorban egyéni szinten definiáltuk a részvételi feltételeket. A kutatás alanyait azon magyar állampolgárok képezik, akik 1979 után születettek, és jelenleg valamilyen felsőoktatási intézmény utolsó két évfolyamának hallgatói, vagy pedig a kiválasztott üzleti szervezetek legfeljebb két éve dolgozó, diplomás munkavállalói.

Másodsorban kiválasztottuk azokat a szervezeteket és felsôoktatási intézményeket, amelyekben fókuszcsoportos beszélgetést kívántunk szervezni. Szervezési indokokból jelenleg fóleg a közgazdasági területre összpontosítottunk, és csak kitekintóleg van múszaki és bölcsész csoportunk. A vállalatok kiválasztásánál az iparági és tulajdonosi háttér szerinti sokszínúségre törekedtünk, valamint arra, hogy végzettségi háttér és szakmai ambíciók szerint is gazdag legyen a minta.

A kérdőívet összesen 154 fiatal töltötte ki, ennek $55,8 \%$-a volt hallgatói kitöltő (tehát oktatási intézményben történt az adatfelvétel) és $44,2 \%$ volt céges pályakezdő (tehát vállalatnál történt az adatfelvétel). A részt vevố cégek számára szervezeti riport elkészítését vállaltuk. (1. táblázat)

A kialakult minta nem tekinthető statisztikai értelemben reprezentatívnak sem az egyének, sem a szervezetek szintjén, de a kutatás feltáró jellegéhez, és gyakorlati szempontú céljaihoz jól igazodik. A kialakult minta demográfiai jellemzóit a tanulmány végén mutatjuk be.

\section{Rövid szakirodalmi összefoglaló}

Saját elemzésünk elvégzése előtt fontosnak tartottuk tisztázni, hogy milyen korábbi megállapításokra építhetünk, illetve milyen nyitott dilemmákra érdemes fókuszálnunk a vizsgált korosztály karrierhez és munkavégzéshez kapcsolódó jellemzőinek a megértése során. Hazai szakirodalom gyakorlatilag nem található

\section{VEZETÉSTUDOMÁNY}




\section{A kutatásban részt vevók}

\begin{tabular}{|c|c|}
\hline \multicolumn{2}{|c|}{ A kutatásban részt vevók } \\
\hline $\begin{array}{l}\text { Oktatási intézmények } \\
\text { (5 darab) }\end{array}$ & $\begin{array}{l}\text { Vállalatok ( } 9 \text { darab, min- } \\
\text { denhol egy fókuszcsoport- } \\
\text { beszélgetés volt) }\end{array}$ \\
\hline $\begin{array}{l}\text { Budapesti Corvinus Egyetem } \\
\text { (BCE) (3 fókuszcsoport) }\end{array}$ & British American Tobacco \\
\hline $\begin{array}{l}\text { BGF / Külkereskedelmi Fóisko- } \\
\text { lai Kar, (1 fókuszcsoport) }\end{array}$ & E-ON \\
\hline $\begin{array}{l}\text { BGF / Pénzügyi és Számviteli } \\
\text { Fớiskolai Kar (1 fókuszcsoport) }\end{array}$ & Ernst \& Young \\
\hline $\begin{array}{l}\text { International Business School } \\
\text { (1 fókuszcsoport) }\end{array}$ & KPMG \\
\hline $\begin{array}{l}\text { Miskolci Egyetem } \\
\text { (2 fókuszcsoport) }\end{array}$ & Magyar Telekom \\
\hline Debreceni Egyetem & McDonalds' \\
\hline & MOL \\
\hline & Procter \& Gamble \\
\hline & T-Online \\
\hline
\end{tabular}

e témakörben, csak néhány rövid, jellemzôen kérdésfelvetéssel megelégedô, inkább a népszerú, elsôsorban az internetes szaksajtóban megjelenô cikk. (Némi öszszehasonlítási alapot jelenthet a 30-as éveikben járó felső vezető́kre vonatkozó korábbi kutatásunk: Bokor -Radácsi, 2006a, 2006b) Ezért az ebben a fejezetben következố szakirodalmi áttekintés a nemzetközi tanulmányokra alapozódik.

Mindenekelôtt egy fontos megjegyzés. Az elméleti és gyakorlati szaksajtót átvizsgálva könnyen megállapítható, hogy a generációs témakör, és azon belül is az Y-generációsok jellemzése nagyon divatos, felkapott kérdés.

Számos problémafelvetô, „guru véleménynyilvánító", valamint empirikus megkérdezések eredményeit taglaló cikk, tanulmány olvasható. A téma népszerüsége azonban láthatóan nem jár együtt a megalapozottsággal és mélységgel. Jól hangzó, ám szlogenjellegú odamondások, izgalmas kérdésfelvetések, egymásnak ellentmondó empirikus tanulságok, tanácsadói sikerrecepteknek megágyazó helyzetértékelések kavarodnak az egész generációs témakört alapjaiban megkérdőjelezô figyelmeztetô hangokkal.

A generációs elméletek kritikáinak jó összefoglalóját adja a Hudson (2005) tanulmány, melynek üzeneteit a következő fóbb pontokban lehet összefoglalni:
1. A generációs elméletek nagy veszélye a sztereotipizálás.

2. Ugyanakkor a generációs elméletek jól eladhatóak, a cikkek leegyszerúsítik a döntéshozók helyzetét.

3. A markáns generációs különbségeket nem erôsíti meg egyetlen átfogó longitudinális kutatás sem.

4. Az értékrendbeli, magatartási, illetve attitúdváltozások lassú folyamatban mennek végbe, nehéz egyértelmú választóvonalakat találni.

5. Ezek a változások sokszor inkább tekinthetôek speciális életciklushelyzet alapján adott válaszoknak, melyek a társadalmi és üzleti szituációhoz illeszkednek, semmint markánsan különböző generációs kohorszok következményének.

Mindezek után kijelenthetjük, hogy szakirodalmi áttekintésünknek nem célja sem a kritikai értékelés, sem pedig a modellalkotó, elméleti helyzettisztázó alapozás. A következőkben csupán a hozzáférhetô szakirodalom üzeneteinek, tanulságainak strukturált áttekintésére törekszünk, mintegy viszonyítási alapot képezve és elemzési ötleteket keresve saját vizsgálatunkhoz.

\section{Generációk a szakirodalomban}

Az egyes generációk eltérô értékvilágával foglalkozó kutatások alapja egy majd' száz éve íródott tanulmány. Karl Mannheim (1928) feltételezése az volt, hogy az embereket fiatal korukban érố benyomásoknak az egész életre (az értékekre, a magatartásra stb.) szóló hatásuk van. A populáris és a szakirodalomban széles körben elterjedt a generációs modellek használata, nem csak az Államokban, hanem a kulturális és gazdasági hasonlóságok miatt Nyugat-Európában is.

A közmegegyezés szerint az egyesült államokbeli munkaerópiacon négy generáció van jelen:

- a már éppen kivonuló, háború elő́tt született Veteránok,

- a háború utántól a 60-as évek elejéig született Boomerek,

- a 60-70-es években született X-generációsok,

- a 80-as évektól született, a munkaerópiacra éppen mostanában belépó Y-generációsok, vagyis a mi vizsgálatunk tárgyát képező korosztály. ${ }^{3}$

A különböző generációk munkaélettel kapcsolatos jellemzơinek megértéséhez jó alapot kínál a 2. táblázat, ahol több publikáció eredményeit összesítettük. (Kaimal, 2003; Lancaster-Stillman, 2002; Pekala, 2001; Riccucci, 2002; Tulgan, 2000)

\section{Az Y-generáció jellemzói}

Mint már korábban jeleztük, az 1980-2000 között születetteket szokás az Egyesült Államokban az Y-generációnak nevezni. A hazai Y-generáció korhatárait illetôen több kiindulási pont is kínálkozik. Jellemez- 
A különbözố generációk munkaélettel kapcsolatos jellemzói

\begin{tabular}{|c|c|c|c|c|}
\hline & Veterán & „Boomer" & X-generáció & Y-generáció \\
\hline Technológia & $\begin{array}{l}\text { Nem jártas } \\
\text { az új technológiákban, } \\
\text { képezni kell. }\end{array}$ & $\begin{array}{l}\text { Nem szokott hozzá, } \\
\text { hogy rábízza magát } \\
\text { az új technológiákra, } \\
\text { ellenáll. }\end{array}$ & $\begin{array}{l}\text { Technológiaőrültt. } \\
\text { A legújabbat akarja. }\end{array}$ & $\begin{array}{l}\text { Internet } \\
\text { az alapvető } \\
\text { kommunikációs eszköz, } \\
\text { megszokta az interaktív } \\
\text { megoldásokat. }\end{array}$ \\
\hline Munkahelyváltás & $\begin{array}{l}\text { A lojalitás } \\
\text { vagy munkaetika } \\
\text { hiányának tekinti. }\end{array}$ & $\begin{array}{l}\text { Tart attól, } \\
\text { hogy a munkahelyváltás } \\
\text { gyengíti szenioritását, } \\
\text { esélyeit. }\end{array}$ & $\begin{array}{l}\text { Alapvetőnek } \\
\text { tekinti a versenyképes } \\
\text { önéletrajzhoz. }\end{array}$ & $\begin{array}{l}\text { Akár egyidejúleg több } \\
\text { karrier építésére is } \\
\text { nyitott. }\end{array}$ \\
\hline Irányítás & $\begin{array}{l}\text { Igényli a világos, } \\
\text { szenioritás alapú, } \\
\text { autoriter vezetést. }\end{array}$ & $\begin{array}{l}\text { Elfogadja } \\
\text { a hierarchikus, autoriter } \\
\text { struktúrákat. }\end{array}$ & $\begin{array}{l}\text { A részvételen alapuló, } \\
\text { demokratikus struktúrát } \\
\text { igényli. }\end{array}$ & $\begin{array}{l}\text { Fontos a döntésekbe } \\
\text { való bevonás, igényli az } \\
\text { önállóságot. }\end{array}$ \\
\hline Viszony a változáshoz & $\begin{array}{l}\text { A hagyományokhoz } \\
\text { való kötódés miatt } \\
\text { a változást } \\
\text { károsnak véli. }\end{array}$ & $\begin{array}{l}\text { Kevéssé rugalmas, } \\
\text { ellenáll a változásoknak. }\end{array}$ & Értékeli a változást. & $\begin{array}{l}\text { Rugalmas munkavál- } \\
\text { laló, maga érdekévé } \\
\text { formálja a változást. }\end{array}$ \\
\hline Lojalitás & $\begin{array}{l}\text { Magától értetődő, } \\
\text { kiemelt értéknek véli. }\end{array}$ & $\begin{array}{l}\text { Lojális, de nyitott } \\
\text { a jobb állásajánlatra. } \\
\text { Elfogadja, hogy } \\
\text { a munkahely szempontjai } \\
\text { sokszor fontosabbak } \\
\text { a magánéletnél. }\end{array}$ & $\begin{array}{l}\text { Egyénekhez, } \\
\text { csoportokhoz és nem } \\
\text { cégekhez lojálisak. }\end{array}$ & $\begin{array}{l}\text { Magához } \\
\text { és személyes } \\
\text { kapcsolataihoz lojális. } \\
\text { A magánélet } \\
\text { prioritásai erósebbek, } \\
\text { mint a munkahelyé. }\end{array}$ \\
\hline Képességek fejlesztése & $\begin{array}{l}\text { Már kiképzettnek érzi } \\
\text { magát. }\end{array}$ & $\begin{array}{l}\text { Attól tart, hogy az utána } \\
\text { jövôk elveszik } \\
\text { a munkáját. }\end{array}$ & A siker kulcsának érzi. & $\begin{array}{l}\text { Alapvetố motiváció, } \\
\text { a munka közben is } \\
\text { keresi } \\
\text { az új információkat. }\end{array}$ \\
\hline Javadalmazás & $\begin{array}{l}\text { Lojalitása miatt hosszú } \\
\text { távon számol. }\end{array}$ & $\begin{array}{l}\text { Lojalitása miatt hosszú } \\
\text { távon számol. }\end{array}$ & $\begin{array}{l}\text { Azonnali jutalmazást } \\
\text { vár, nem hisz a munka- } \\
\text { helyi biztonságban. }\end{array}$ & $\begin{array}{l}\text { Teljesítmény alapú } \\
\text { bérezést igényel, } \\
\text { saját piaci értékének } \\
\text { figyelembevételével. }\end{array}$ \\
\hline
\end{tabular}

hetnénk óket úgy is, hogy ez az a generáció, akiknek a szocializációjára már nem, vagy csak elhanyagolható mértékben hatott az elózố rendszer. Ez esetben a kb. 1982 után születetteket sorolhatjuk ide. (Ez egyben azt is jelenti, hogy a hazai Y-generáció alapvetô szocializációja már jelentôs mértékben a fogyasztói társadalom keretei között zajlott.) A munkaerópiac felól kiindulva azok tartoznak az új generációba, akik a rendszerváltást követô nagy „munkaerô-piaci boom”-ot lekésve, valamikor az ezredforduló környékén kezdik pályájukat. Ez esetben akár az 1975-ös évet is tekinthetnénk a generáció indulási pontjaként.

E kutatásban egyfajta középutat is választva, valamint a külföldi eredményekhez való összehasonlíthatóságot is figyelembe véve az 1980-as évtól születetteket soroljuk a vizsgálati célcsoporthoz tartozóknak. (A mintavétel során néhány 1978-79-ben született fiatal is bekerült a fókuszcsoport résztvevői közé.)
A megvizsgált Y-generációs tanulmányok viszonylag keveset foglalkoznak a karrier témájával. Talán ez azzal magyarázható, hogy e generáció kapcsán jelen pillanatban egyelôre még az elérésük, vonzásuk, kiválasztásuk és motiválásuk a legfontosabb téma, kevésbé a jövốbeni lehetôségeik.

A következó tanulságok fogalmazhatók meg az feldolgozott cikkekból (Hudson, 2005; Kaimal, 2003; Leonard, 2001; Northwest Regional Educational Laboratory, 2005; Ruiz, 2006):

- Kiindulópont számukra a karrier kettôs felfogása. Azaz nem fogadják el, hogy választani kell a szakmai karrier (nagy pénz), és a családalapítás között. Mindkettốt akarják és mindkettő elérését el is várják önmaguktól, illetve a munkahelyüktôll.

- Nem befektetésként élik meg a munkát, azonnali előnyöket akarnak. Nem akarnak nagy áldozatokat hozni a munkájuk érdekében. 
- Nem várják el, hogy karrierpályájuk egyenesen felfelé íveljen. A korábbi generációknál nyitottabbak az azonos szintû, más területról való tapasztalatszerzés iránt, és nem feltétlenül vezetôi karriert terveznek csak.

- Jellemzően még csak rövid távú karrierelképzelésekkel, célokkal rendelkeznek, sokszor nem is gondolják végig az adott munkakörön túlmutató fejlődési lehetőségeket a munkaválasztás során.

- Fontos elvárás részükról a folyamatos fejlődés élménye, a korábbi generációknál nagyobb hangsúlyt helyeznek a személyes tanulásukra.

- Megjelenik az értelmes vagy értelemteli munka (meaningful work) koncepciója, mint alapvetô vágyuk. Azaz nem elégséges számukra a feladat-végrehajtás, hanem olyan tevékenységekért akarnak felelősséget vállalni, amelynek világos a következménye, ráadásul értelmezhetô értéket is teremt.

- Már az első munkanaptól fogva feleloosséget igényelnek, nagy elvárásaik vannak magukkal szemben, jobbak akarnak lenni elôdeiknél és folyamatosan tanulni szeretnének (a kollégáktól is). Talán ez is magyarázza, hogy miért hagyják ott az átlagosnál gyakrabban a munkaadóikat: nem arról a fajta türelmetlenségról van szó, hogy előre akarnak jutni, hanem olyat akarnak tudni, csinálni, amit eddig nem, és ezáltal bizonyítani önmaguknak.

Nehéz mérleget vonni az előzőekben bemutatott számtalan generációs jellemzố kapcsán. A korábbi generációkhoz képest úgy túnik, hogy a „Baby Boom”-erek lojalitásához és anyagiasságához képest, esetükben a függetlenség és a tanulás/fejlődés értékeit hangsúlyozzák. Az idősebbeket a szervezeti hierarchia és bürokrácia elfogadása jellemzi, az Y-generáció esetében a személyes és a munkavilág egymásba olvadásáról, a „munkahelyek” hangulatának megfiatalításáról írnak.

A X-generáció sikerorientáltságával és individualizmusával szemben pedig munka és magánélet teljességére való törekvést, az áldozatvállalás elutasítását, valamint egy újszerú (virtuális, sokszor elektronikus) alapú közösségi élet megerósödését emelik ki. Ezek a jellemzók egyfajta idealizálásnak is túnhetnek, mintha ettôl a generációtól várnák a jelenlegi szakírók a korábbi nemzedékek problémáinak megoldását és hibáinak a jóvátételét. Legalábbis ezt szeretné üzenni a legtöbb róluk szóló publikáció. Ideje megmutatni, hogy milyen eredményekre jutottunk a hazai felmérésünk során.

\section{Hazai eredmények: Karrierkép és célok}

Az empirikus eredményeink közül a következókben bemutatjuk a megkérdezett fiatalok karrierre, magánéletre és a kettő közötti kapcsolatra vonatkozó elvárá- sait és céljait. A fókuszcsoportot kísérô kérdôív szúkre szabott kereteinek megfelelően egyes szempontok szerint lehetôség nyílt a kutatás korábbi részében felvett, nagymintás kérdôívvel való összehasonlításra is.

\section{Mit jelent a karrier szó számukra?}

Megkérdeztük, hogy milyen szavak mentén értelmezik a karrier szó jelentését. (Mindenki 5 szót említhetett a kérdőívben.) Az eredmények szinte kísértetiesen megegyeznek a korábbi SHA-felmérés adataival. Vagyis a leggyakrabban és a sorban legelőször említett - egyetlen - szó a „siker” volt. (90-en említették, ebból 56-an az első́ helyen.) Ebben talán nincsen semmi meglepő, közhely, hogy az emberek sikeresek akarnak lenni, illetve mai köznyelvben a karriernek valóban szinonimájává vált a siker szó. Mégis érdemes lehet egy pillanatra megállni ennél az eredménynél, és komolyan végiggondolni az üzenetét, akár többféle szemszögból is:

- Fontos különbség, hogy míg például a pénz és az elómenetel korlátozott ,jószág"-ok egy szervezetben, addig a siker nem az. Van valami, ami nagyon fontos a munkavállalóknak, és ezt úgy adhatja a szervezet és a vezető, hogy közben neki sem lesz kevesebb belóle.

- Persze nyomban felmerül a - kissé költői - kérdés, hogy vajon hány vezető, illetve HR-es gondolja azt, hogy az a dolga, hogy sikeressé tegye az embereit? Hányan észlelik vagy tartják fontosnak ezt az elvárást, és hányan képesek ezt lefordítani a gyakorlat nyelvére?

- Természetesen a siker nagyon általános szó, rögtön fel kell tenni a kérdést, hogy egyáltalán mitôl érzik magukat sikeresnek az emberek? Kérdés azonban, hogy ezt a kérdést egyáltalán hány szervezetben fogalmazzák meg.

- A siker iránti igény tudatosítása a lehetőségek mellett csapdákat is rejt. E szóban ott van például a sportbeli áthallás, azaz a versengés, az összemérés üzenete is. Ott van a megfelelés, a külsố mérce is - például mennyiben más a siker, illetve a boldogság szavak asszociációs köre. A sikerre törekvő ember nyilvánvalóan függ a környezetétól, annak folyamatos visszajelzéseitől, az elvárás szintjétől. S a sikerben ott van a kudarc, a hanyatlás is, hiszen a csúcs után szükségszerúen következik a hullámvölgy.

Ha azonban az értelmezésük alapján kialakított - rokon értelmú szavak összevonásából képzett - szócsoportok szintjén végezzük el az elemzést, akkor kiderül, hogy a sikerességnél is gyakrabban kapcsolják össze a pénz és az egzisztencia képeit a karrierrel, akárcsak az idősebb korosztályban végzett felmérésnél (1. ábra).

A gyakoriságok azt mutatják, hogy három tényezố messze kiemelkedik az asszociációk köréból, így elmondhatjuk, hogy a megkérdezett fiatalok számára 
Mit jelent a karrier?

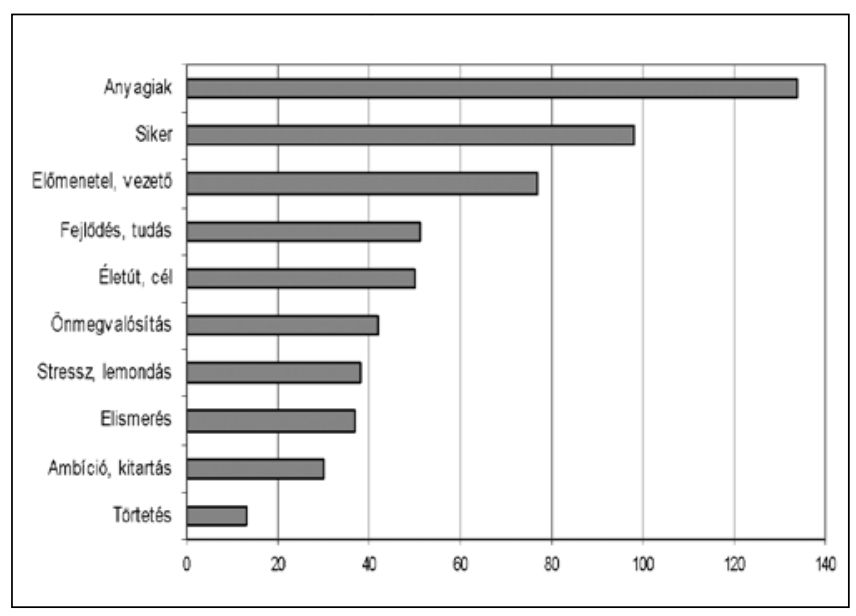

a karrier elsősorban egzisztencia-teremtést, sikert és vezetôi pozíciót jelent. Ezek után következnek csak a szakirodalom által belsô motivációként jellemzett tényezók, mint a fejlódés, illetve az önmegvalósítás. A legjellemzóbb asszociációk sorrendje, de még az aránya is szinte kísértetiesen megegyezik az SHA-felmérésben kapott eredménnyel. Vagyis a válaszok nem utalnak arra, hogy jelentősen eltérő karrierértelmezéssel rendelkeznének a most munkaerópiacra lépók, mint a korábbi korosztályok. A klasszikus, vagyis a létramászásra és anyagi sikerekre épülő karrierértelmezést vallja a többség. A sorrend egyben azt is sugallja, hogy a vezetối karrier indokai között kiemelt szerepet kap az anyagi háttér biztosítása. Vagyis nem a vezetôi életpálya tartalmi elemeihez - felelôsség, alkotás, döntéshozatal, mások fejlesztése, hatalom - kapcsolódó motivációk a meghatározók.

További meglepetéssel szembesülünk, ha figyelmünket a fejlődésnek a karrierhez kötődő asszociációkban (tanulás, tudás, önmegvalósítás stb.) betöltött szerepére fókuszáljuk.

A válaszadó fiatalok kétharmada esetében meg sem jelennek a fejlôdéshez kapcsolódó szavak a karrier fogalmában. Érdekes módon szinte csak lányok körében fordul elő, hogy a fejlódés domináns a karrier értelmezésében. (2. ábra)

\section{Mennyire vélik önmagukat tehetségesnek?}

A kérdőívben az előző kutatási ággal összehasonlítható módon azt is felmértük, hogy mennyire ítélik tehetségesnek szakmai és vezetôi szempontból magukat a válaszadók. Természetesen a résztvevoók szubjektív önértékelésével van itt dolgunk, nem pedig tényadatokkal. Az eredmények egyfelól annak a hipotézisnek a tesztelésére alkalmasak, miszerint a jelenleg végzók,
Mennyire jellemzố a fejlódés a karrierasszociációban?

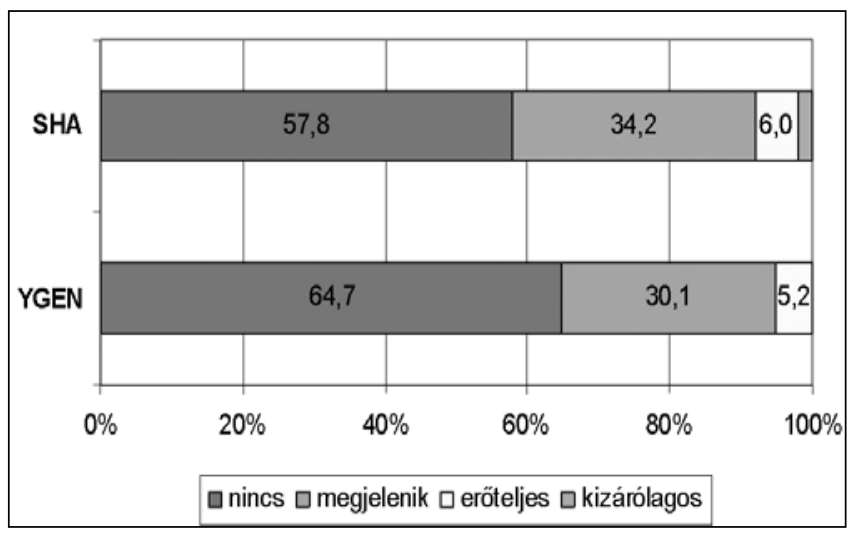

és különösen a pesti közgázosok, túl magasra értékelik magukat és tehetségüket.

Összességében elmondható, hogy a válaszadók az átlagnál tehetségesebbnek vélik magukat, ám nem kiugró mértékben. Mindez azt jelenti, hogy felük gondolja magát átlagosan, másik fele pedig átlagosnál jobban tehetségesnek, és elenyésző, 4-6\%-os arányban kimagaslóan tehetségesnek. (A pszichológiai elméletek természetesnek tekintik ezt a fajta általános pozitív önképet.) A szakmai és vezetói tehetségük megítélése között nincsen lényeges különbség. A korábbi felméréshez viszonyítva sincsenek meghatározó eltérések. (3. ábra)

\section{3. ábra}

Mennyire vélik önmagukat tehetségesnek?

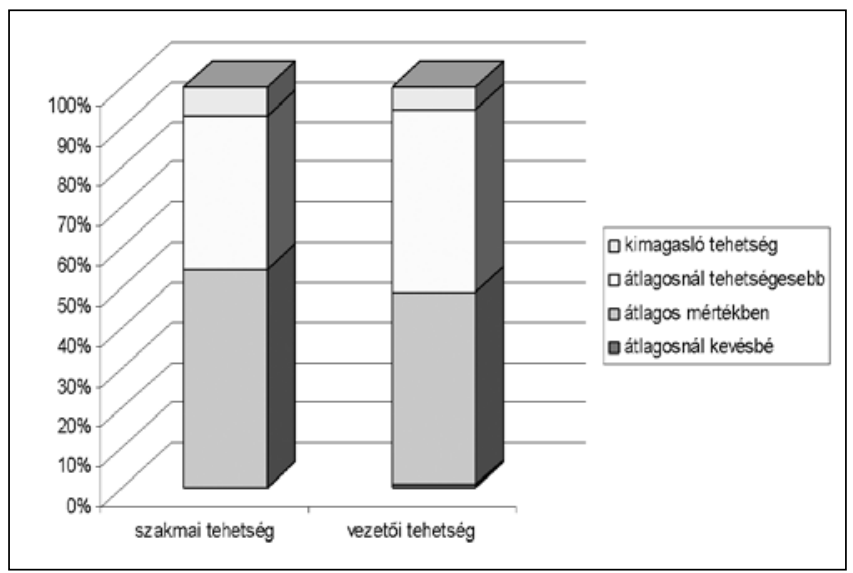

A szakmai tehetségüket magasabbra értékelik az egyetemi végzettségúek, vezetôi szempontból azonban nincsen különbség. Az eredmények nem támasztják alá a közgázosok kiemelkedő (túlzott) önértékelését, eredményeik teljesen belesimulnak az átlagba. Az IBS-ben végzettek azonban vezetôi szempontból kiemelkedôen magas önértékeléssel rendelkeznek. 
Úgy tûnik, a hölgyekben eleve múködik egy önleértékelô mechanizmus: miközben szakmai tehetségüket egyformára értékelik a fiúkkal, addig a vezetôi tehetségüket - a 4 fokozatú skálán - 0,5-tel alacsonyabbra, csak átlagosra értékelik. Kérdés, hogy vajon a fejükben lévő ideális vezetókép „férfias” jellege, a vezetői pálya és a gyerekvállalás nehéz összeegyeztethetôsége jelenik-e meg ebben az eredményben. Az látszik azonban, hogy az üvegplafon nemcsak kívül, a szervezeti valóságban, hanem belül, a saját fejükben is létezik. A korábbi, SHA-felmérés eredményei szintén ugyanezt a jelenséget mutatták, tehát nem generációs jellemzővel állunk szemben, bár ott már szakmai szempontból is megjelent a leértékelés. Erre magyarázat az lehet, hogy a felsőoktatásban még kevésbé érzódik a nemek közötti diszkrimináció, sôt jellemzően a lányok kifejezetten jobb tanulmányi eredményekkel végeznek, ami növelheti a saját szakmai tehetségükbe vetett hitüket.

Az érzékelt tehetség egyébként pozitívan befolyásolja a megcélzott hierarchiabeli szintet, az elvárt jövedelmet, miként a karrier menedzseléséért érzett saját felelősséget is. Ennyiben tehetségükról alkotott önképük a karrier-elképzeléseiket meghatározó kiindulópontnak tekinthető, ami jó hír.

\section{Mit tettek a karrierjükért: munka melletti tanulás, gyakorlatszerzés}

A kérdőívek adatait feldolgozva egyértelmúen kijelenthetô, hogy mára szinte mindegyik diák végez hosszabb-rövidebb ideig valamilyen munkát tanulmányai mellett. A válaszadók majd' 93\%-a jelzett munkatapasztalatot, vagyis gyakorlatilag mindenki dolgozik/ dolgozott is a tanulás mellett! Ez a jelentôs munkatapasztalat a 3. táblázatban található szervezetek és formák között oszlik meg.

\section{3. táblázat}

\section{Hol szerez korlatot?}

\begin{tabular}{|l|c|}
\hline & $\begin{array}{c}\text { Összes válaszadóhoz } \\
\text { képest }\end{array}$ \\
\hline Üzleti szervezetben gyakornok & $35,2 \%$ \\
\hline Diákszervezet & $26,9 \%$ \\
\hline Üzleti szervezetben munkatárs & $24,8 \%$ \\
\hline Családi vállalkozásban besegítés & $17,9 \%$ \\
\hline Önkéntes munka & $15,2 \%$ \\
\hline Demonstrátor & $11,7 \%$ \\
\hline Egyéb & $11,7 \%$ \\
\hline Civil szervezetnél munkatárs & $10,3 \%$ \\
\hline Saját vállalkozás & $5,5 \%$ \\
\hline
\end{tabular}

Látható, hogy a munkatapasztalatok döntő többsége nem kisegítő jellegú, idényjellegú, gyors pénzkereseti forrást jelentô munkákat jelent. A jelen válaszok azt mutatják, hogy a vizsgált korosztály tagjai gyakran és szorosan kötelezôdnek el a munka világa mellett. A diákévek alatti gyakori munkavállalás motivációi egyértelmúen rajzolódtak ki a válaszokból.

1. A legtöbben karrierépítési indokkal keresik ezt a megoldást. Azaz szeretnék elkerülni azt, hogy késôbb pályakezdốként menjenek ki a munkaerópiacra, hanem már olyan tapasztalattal akarnak rendelkezni, ami értékesebbé teszi óket. Ez egyben azt is jelentheti, hogy letudják a munka érdektelenebb, „fénymásolós" részét már az iskolaévek alatt. A gyakornoki programok sokszor elôválasztásként is funkcionálnak, letesztelhetik elképzeléseiket és elvárásaikat az adott iparágra vagy cégre vonatkozóan. Ez a fajta megközelítés nagyon tudatos, munkaerő-piaci értéknövelő stratégiaként jellemezhetô.

„Nekem végig, szinte kezdetektól ott lebegett a szemem elótt, hogy kell valami extra, amivel kiemelkedek, dolgozni, szakmai gyakorlatot csinálni. Fóiskolán van kötelezó munkavégzés, egyetemen nincs. Ott járt a szemem elótt, hogy tulajdonképpen hátrányban leszek a fóiskolásokkal szemben, ha nem csinálok valamit, nem dolgozom, akkor a saját évfolyamtársaim közül sem tudok majd kiemelkedni." (12)

„Elkezdtem dolgozni az iskola mellett, nagyon fontos, hogy legyen munkatapasztalata az embernek. Az álláshirdetésekben kevés pályakezdốt, gyakorlat nélkülit keresnek, tapasztalattal könnyebb az elhelyezkedés. (2)

2. Egy kisebb csoportra egyszerúen a szakmai gyakorlat keresése a jellemzó. Ez elófordulhat azért is, mert ez kötelezô, mint például az IBS, vagy más főiskolák esetében. Találunk erre azonban olyan példát is, hogy egyszerúen csak tanulni, illetve külföldi tapasztalatokat gyújiteni akarnak a hallgatók.

„Sokan végzünk önkéntes tevékenységet. Minden félévben van gyakorlat. Belelátunk a szakmába, ott vagyunk testközelben, érezzük.” (6)

3. A válaszolók jelentôs részénél azonban elsôsorban az anyagi motiváció a döntố a munkavállalás során. Akár azért, mert a megélhetésük, illetve különbözó igényeik megkívánják, akár azért, mert szeretnének függetlenebbek lenni szüleiktól. Ez a fajta motiváció nagyon sok esetben nem a saját képzésükhöz igazodó szakmai munkát jelent. (Fizikai munka, hostessként való dolgozás, nyelvtanítás stb.) „14 éves korom óta dolgozom az iskola mellett, volt sok „szép” munka, hütóház, éjszakai meló, büdös, mocsok. De volt olyan is, hogy csokigyárban, metró- 
ban dolgoztam egy évig. Semmi szakmai, csak hogy megélhessek." (14)

„Kis könyvelóirodák szeretnek PSZF-est foglalkoztatni, fóleg a tavaszi idószakban, akkor vannak zárlati munkák. Nem nézik, hogy milyen érdemjegyekkel végzett az ember, számvitel szigorlatot sem követelnek meg, elég a feltétel, hogy a PSZF hallgatója. Vannak hallgatók, akik órára egyáltalán nem járnak, akik minden nélkül beülnek könyvelni valahová, 700 forintos órabérért, ez rabszolgamunka." (11)

A korábbi tapasztalatokhoz képest tehát fontos váltásnak, és a karriertudatosság erősödésének tekinthető a karriercélú munkavállalás. Annyi kiegészítést érdemes azonban tenni, hogy több csoportban is úgy túnt, hogy ezt elsôsorban kényszernek tekintik a hallgatók - nem tehetik meg, hogy lemaradjanak a versenyben. A döntés tehát nem egyfajta belső vágyra, tervezésre épül, hanem erôsebb a külsô kényszerítô körülményekbool levezetett lépéskényszer. Ez viszont felveti a kérdést, hogy valóban karriertudatosságról van-e szó, vagy inkább sodródás látható. Egyfajta hiedelemre, közös pszichózisra alapul ez az attitưd, ami nyílván öngerjesztő és önbeteljesítő hatással is bír. Különösen a Közgázon tưnik nagyon erôsnek ez a versenyhangulat, a következő összes idézet az ottani fókuszcsoportokból való.

„Szeretnék dolgozni a diploma végéig, mert nagyon fontos, hogy az egyetem alatt is csináljunk valamit. Harmadévesként elkezdtem filózni: kikerülök az egyetemról, lesz diplomám, de lesz még egy csomó embernek diplomája, és ha semmi pluszt nem tudok felmutatni, nem vagyok semmi szervezetnek a tagja, nem csináltam semmit, akkor nehezebb lesz." (16)

„Rossznak látom ezt az elindult folyamatot. A tanárok is hibásak, ók is arra buzditanak, hogy ez jó. Senki nem tanulja meg, amit kell, mert nem jár be órákra, pedig tök érdekes elóadások vannak. Ma voltam egy olyan elóadáson, egy cég szakmai életéról, marketingról szólt, mit, hogy csinálnak. 15-en voltunk a 100-ból, szomorúnak tartom.” (1)

Többek véleményében megjelenik a kiszolgáltatottság érzése. A szervezetek tudják, hogy a diákok rászorulnak a tapasztalatszerzésre, illetve a pénzre. Mindkét fajta dilemmára sok példát hallhattunk. Egyfelól a korábbi idézetekben is többször megjelent, hogy egyes cégeknél gyakorlatilag teljes idős munkát várnak el a nappali tagozaton tanuló hallgatóktól, és nincsenek tekintettel a tanulási helyzet kívánta igényekre. Másfelől pedig felbukkant az ingyen, vagy pedig nagyon olcsón végzett munka elvállalásának dilemmája is.

„Ahová pályáztam, nem tudom hányan jelentkeztek, de sokan biztosan. Csomó helyen úgy van, hogy nem fizetnek érte. Ezt nehéz bevállalni, az idô nagy részét erre forditod, kevesebb idó van a tanulásra, ez nem egészen korrekt." (10)

„Csodálkozom, hogy úgy hirdeti meg a gyakornoki állást, hogy 40 óra. Mondom: nappalis vagyok, azt mondja erre, nem kell iskolába járni, valamit valamiért. És akkor minimálbért fizet." (1)

A munkavállalás azonban sokak számára teljesen pozitív döntés. Vannak lelkes és tehetséges emberek, akik komoly karriert futnak be gyakornokként. Ehhez persze az kell, hogy gyakorlatilag kiegészítő tevékenységnek tekintsék az egyetemet, szinte csak a papír megszerzésére redukálva célkitúzéseiket.

Egyetemi oktatóként ugyanakkor nem szabad elmenni a következő dilemma mellett. Nem fizetnek-e mind a hallgatók, mind pedig a szervezetek túl nagy árat ebben a versengésben? Kétségtelen, hogy a hallgatók rövid távon jobb anyagi helyzetbe kerülnek, előnyösebb pozíciókkal indulnak a munkaerópiacon, a cégek viszonylag olcsó munkaerôhöz jutnak, olyan munkákat tudnak elvégeztetni, amelyek sokszor nem motiválóak a már bent lévő alkalmazottaiknak. Ugyanakkor szinte kimaradnak, vagy csak felszínessé válnak az egyetemi évek, amelyek mind a szakmai és az általános értelmiségi tudás és kompetenciák fejlődése, mind pedig az érett, független felnôtté válás szempontjából fontos idôszakot jelentenek. Szó se róla, nyilván az is kérdés, hogy az egyetemek jelenleg tudják-e mindezt biztosítani.

\section{Konkrét karriercélok, elképzelések}

A legkonkrétabb karriercél elsősorban a vezetővé válás kapcsán hangzott el. E kérdéssel kapcsolatban egyébként a kérdőív eredményeit is segítségül hívhatjuk, hiszen szerepelt ott egy olyan kérdés, hogy milyen hierarchiaszinten szeretnének öt év múlva dolgozni.

A válaszok erôs vezetôi motivációról, és komoly előrejutási szándékról (álmokról?) árulkodnak. Lényegre töróen fogalmazva: öt év múlva már szinte senki sem szeretné egyszerú beosztottként látni magát! (Még az sem, aki most esetleg csak 4. éves az egyetemen vagy 3. éves a fooiskolán.) Ráadásul, mint látható a nagy többség nem is egyszerúen egy alsó szintú vezetôi posztot céloz meg, hanem legalább kettő, de akár három vezetői szintet is szeretne előrelépni! Elképesztően magas, és egyben irreális igények ezek, tekintve azt, hogy amúgy is egyre kevesebb a vezetói pozíció, amelyeket amúgy is viszonylag fiatalok töltenek be.(4. ábra)

Érdemes észrevenni, hogy a kiemelt szakértői pozíció kismértékben népszerúbb az alsó vezetői pozíciónál. Feltehető́n egy olyan, viszonylag jelentôsebb létszámú - és a fókuszcsoporton motivációiknak hangot is adó - csoportról van szó, aki keresi a szakmai

\section{VEZETÉSTUDOMÁNY}


4. ábra

Karriercélok

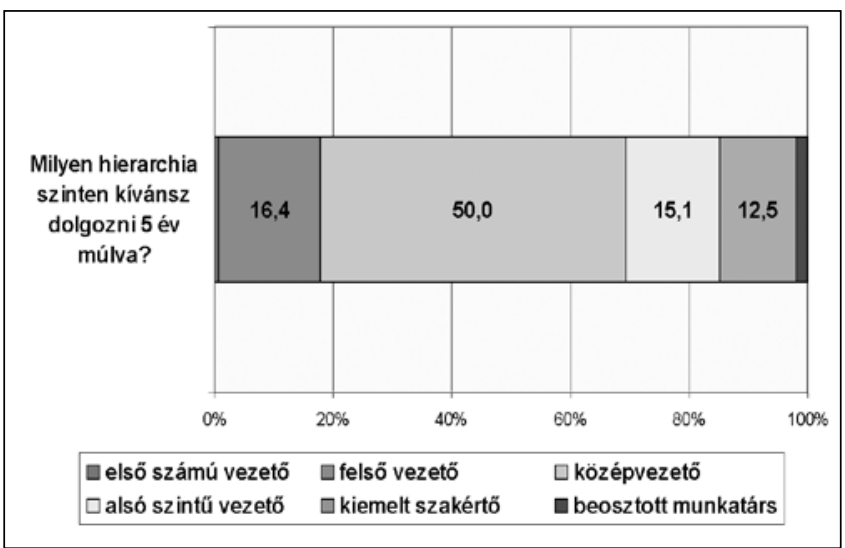

kihívásokat és felelősséget, de magasra értékeli a függetlenséget, és nem kívánnak embereket vezetni.

A vezetôvé válás vágya mindenféle bontásban erôsnek mondható. Nemek szerint annyi különbség van, hogy a lányok többsége megelégedne a középvezetői szinttel, a felsô vezetói pozíciót ennyi idő alatt elérni szándékozók szinte mind fiúk. Van a kitöltóknek egy olyan csoportja, aki tehetségesnek tartja magát vezetői szempontból, ám nem kíván magasabb vezetôii pozíciókban dolgozni. A részletesebb elemzések azt mutatják, hogy e csoport elsôsorban lányokból áll. Tehát itt ismét tetten érhető egyfajta önkorlátozó mechanizmus a hölgyek esetében.

A közgazdász végzettségúeknél kiugróan a legmagasabb a vezetối motiváció, ók valóban nem tudják elképzelni, hogy munkatársi szinten maradjanak. A fóiskolai vagy egyetemi háttér nem jelent megkülönbözető tényezôt.

A vezetói pozíciót hosszabb távon is elutasítók egyébként legtöbbször a kellő „keménység” hiányával magyarázzák hozzáállásukat. Érdekes, hogy miközben a statisztikával kapcsolatban az derül ki, hogy nagymértékben vezetôii pozíciókba készülnek, kevés tartalmi pozitívumot említenek ennek kapcsán. Óket hallva elsősorban inkább a vezetéssel együtt járó terheket ismerhetjük meg, a felelősségről is mint teherről beszélnek leginkább. A vezetói munka annyiban vonzó, hogy elismertséget jelent, nagyobb szakmai tudást és tapasztalatot feltételez a szemükben, ám sok teherrel jár, és nem feltétlenül előnyös személyiségvonásokat - lásd keménység - igényel.

„Nem szeretnék felsố vezetó lenni, mert nem vagyok alkalmas, nem vagyok elég kemény, nekem egy középvezetôi szint jó lenne." (9)

„Át kell látni az egészet, hogyan múködik, összeszokni az emberekkel, alkalmazkodni, segíteni a másiknak, együttmúködni. Ha ezt jól átlátja az ember, ha bírja a felelösséget, ezért szerintem egy vezetónek sokkal több idót kell a munkájára szánni, mint egy beosztottnak. Nem is biztos, hogy szeretnék az lenni."(16)

Összességében az ismertetett statisztikák és az elhangzott szövegek is azt erősítik meg - különösen kiegészítve a késốbb következô sikerkritériumok és a pénz témájának elemzésével -, hogy az erôs vezetői motivációk mögött nem tartalmi vagy belső késztetések állnak, hanem inkább a pozícióval együtt járó elismertség és egzisztencia a fó hajtóerô. Vagyis a csoportokon elhangzottak alátámasztják azt a karrier értelmezése kapcsán már levont tanulságot is, hogy nem önmagában a vezetői pozíció jelenti a célt, hanem az ezzel járó kompenzációs csomag, és a megvalósítható életszínvonal.

Azt gondoljuk, hogy nagyon keveseknek van tudatosan megfogalmazott karriercélja. Rövid távon, az elsố munkakörre vonatkozóan esetleg rendelkeznek konkrétabb elképzeléssel, hosszabb távra előretekintve inkább egzisztenciális igényszintjük van, és ehhez - folyamatosan - igazodva alakítják konkrét munkahelyi céljaikat. Vagyis kevésbé a munkavégzés jellemzői, hanem inkább az érte kapott elismerés és kompenzáció jelenti a karrier célját. (Ismét a külsố irányítottság túnik jellemzóbbnek a belülrôl való vezéreltség helyett.)

\section{Mit jelent sikeresnek lenni?}

A karrierasszociációk statisztikai elemzésénél láthattuk, hogy a siker szó szorosan kapcsolódik a karrier értelmezéséhez. A fókuszcsoportok lehetôséget adtak arra, hogy mélyebben megértsük, mikor is érzik majd magukat sikeresnek a megkérdezett fiatalok.

A munkahelyi siker definíciója, mint majd látni fogjuk, erősen kapcsolódik a családi biztonság és egzisztencia megteremtéséhez, de felbukkannak más szempontok is.

- Olyan pozíció, szerep elérése, ami révén lehetséges az egzisztenciateremtés és -fenntartás a család számára. Ez egyértelmúen fontos sikerkritérium, gyakorlatilag e nélkül nem érezhetik elégedettnek, sikeresnek magukat. Fontos észrevenni, hogy itt nem csupán anyagiasságról vagy fogyasztás-orientált gondolkodásmódról van szó, hanem a függetlenségról, és ennek hátterében a felnőtté válásról is. Itt gyakorlatilag két vágy is kimondódik: 1. „Ne szoruljak arra, hogy mások tartsanak el.” 2. „Azon az életszínvonalon éljek, amit elterveztem."

„Nekem az a legfóbb, hogy képes vagyok eltartani magam, hogy önállóan úgy tudok élni, amilyen színvonalon én elképzeltem. Ezzel a büszkeséggel, hogy igen, ezt megcsináltam, nem anyuéknál lakom, mindent, amit ezelótt ók adtak meg nekem egy jobb színvonalon, azt képes vagyok magamnak is megadni." (12) 
„30 évesen, hogy igen itt van ez a srác, valamit elért, szakértó, vezetói állás, pozíció, megfizetik, miután megfizetik, családjának olyan biztonságot tud nyújtani, hogy nyugodtan tudnak élni." (8)

- A siker kapcsán többször felmerül az érdekes, kreatív munka. Konkrétabb tartalom ezzel kapcsolatban ritkán hangzik el, úgy beszélnek a vágyaikról, hogy azok kellően általános szinten maradnak. (Mintha nyitottak lennének arra, hogy mások - szervezetek, fơnökök, ismerősök - definiálják az ô vágyaikat. Csak figyelni kell arra, hogy a megfelelő hívószavakat: kreativitás, önállóság, érdekes munka használják.) A kevés konkrétum alapján végül is két szempont szerint lehet megragadni a számunkra sikeres munkavégzés tartalmi jellemzóit:

- A legkonkrétabb megfogalmazások arra vonatkoztak, hogy az érdekes munka abban jelenik meg, hogy lehetôségük van belevinni a saját ötleteiket, elképzeléseiket is.

- „Hogy elmondhassam, hogy csináltam valamit. Amitól egy-két embernek már jobb lett, olyat csinálok.” (1)

- Egy további azonosítható sikerkritérium az elismertség, ami leginkább szakmai tudáson, tapasztalaton alapszik a szemükben. Azaz legyen nevük, ôket keressék bizonyos problémák megoldása érdekében. Ez a szempont a múszaki végzettségúeknél, a mérnököknél bukkan fel kifejezetten erôsen.

„Amit én szeretnék: ha úgy rakom le a telefont, hogy valaki azért hivott fel, hogy gyere ide, mert összeomlott a rendszer, és van 3 nap, hogy megcsináljuk. Azért hivott engem, mert tudta, hogy én képes vagyok megcsinálni. De ahhoz, hogy az ember kitünjön a többi közül, ahhoz szakértelem és tudás kell. Jó sokoldalúnak lenni, de van olyan terület, amiben az embernek nagyon jónak kell lenni." (1)

„Nagy dolog, ha a szaktársak elismernek. Ök ismerjenek el, a külvilág csak a szép, színes csomagolást látja."(14)

A közvetlen munkához kapcsolódó jellemzóknél gyakrabban bukkan azonban fel az a fajta siker megfogalmazás, ami a családi siker és a munkasiker összekapcsolására vonatkozik, az egyensúly, a stabilitás képeivel. Az alapvetố elvárás az, hogy a kettô közül az egyik - jellemzóen a munka - ne menjen a másik kárára.

„A legnagyobb siker? A lányoknál kardinális kérdés: ha meg tudnám oldani, hogy a családommal is normálisan tudjak lenni, megfeleló színvonalat biztosítani nekik, a munkából se maradjak ki, tudjam a karrieremet is épiteni." (3)

„Két szép gyerek, egy férj, és 50. házassági évforduló. Ez, semmi más. A boldogságot az jelenti, hogy család, és gyerekeim legyenek, megadhassak nekik egy jobb minốségú életszínvonalat. Nem akarok nagyon gazdag lenni, nem akarom hülyére keresni magam, annyit szeretnék keresni, hogy el tudjam tartani a családomat, remélem, a férjem is segít."(1)

A családtervezéssel részletesebben külön alfejezetben foglalkozunk. Itt csupán két dolgot emelünk ki:

- Család nélkül nincsen sikeresség. Sót, mintha a munkaéletbeni sikeresség célja is inkább a családi élet sikerességének a biztosítása lenne. Mindez azt jelenti, hogy legalábbis az előzetes elvárások szintjén, hiába lesz valaki sikeres karrierjében, ha az nem párosul az elvárt családi háttér megteremtésével, akkor önmaga és környezete szemében is sikertelen lesz.

- A családi háttér sikerességének pedig meglehetősen egyértelmú a definíciója, a hagyományos, tradicionális kép szerinti családról van szó: egyetlen, tartós kapcsolat és apaság/anyaság, két/három gyerekkel. A tervek szintjén tehát kifejezetten családorientált életszemlélettel rendelkeznek a pályakezdô fiatalok. ${ }^{4}$ A munkáról gondolkodva azt nem elkülönítve, önmagában értelmezik, hanem folyamatosan a magánéletbe, családba való beágyazottságával együtt kezelik. Hol általánosságban, és talán kicsit kötelező „,körként” is, hol konkrétabban és tudatosan. Alapvetô trendnek gondoljuk, hogy a munka és magánélet (WLB) egyensúlya, illetve ezek a teljességében felfogott célok, már fiatal korban megjelennek a munkavállalók döntési szempontjai között. Nem gondoljuk, hogy rövid távon meghatározó hatásuk van, hiszen majd látni fogjuk, hogy az elsố években hajlandóak áldozatokat hozni az egyik oldal érdekében, ám szándékaik szerint ez nagyon rövid idôtávon megengedhetố csak.

A téma kapcsán még egy apró megjegyzés: a jövőról, a célokról és a sikerról beszélve egyetlen fókuszcsoporton, egyetlen esetben sem merült fel az ,értelmiségi" szó, akár negatív, akár pozitív értelemben sem. Ez a kifejezés mintha teljes mértékben elvesztette volna az identitásformáló erejét.

\section{Milyen áldozatokkal jár a karrier építése?}

$\mathrm{Az}$ áldozat témaköre szemlátomást komoly érzelmeket és vitákat kavart, különösen azoknál a csoportoknál, ahol a már dolgozó fiatalokkal beszélgettünk. Élethelyzetuik egyik alapvetố mintája ragadható meg ezen a témakörön keresztül. Nagy többségük számára egyértelmú, hogy áldozatokat kell hozni a karrierjükért. Sớt, a legtöbben úgy gondolják, hogy a jelen idôszak és a még következó pár év kifejezetten az áldozat vagy befektetés időszaka. Rövid távon ezt kevésbé érzik veszélyesnek, sốt tudatosan így építik fel az életstratégiájukat, ám hosszabb távon már félelmek és változtatási szándék jellemzi ezt a témakört.

\section{VEZETÉSTUDOMÁNY}


A rengeteg szöveg üzenetét gyakorlatilag pár egyszerú, világos mondatban össze lehet foglalni, és ezekkel az állításokkal szinte minden megkérdezett egyet is értene:

- A munkakezdés utáni első 4-5 év a sikeres karrier- és egzisztenciaalapítás érdekében történó befektetés, az áldozathozatal időszaka.

- A munkaadók ebben az időszakban nagy munkaterhelést rónak rájuk, és hosszú munkaidőt követelnek meg.

- Ennek az idôszaknak az ára a magas stressz, és a magánélet jelentős mértékú feláldozása, de ez „benne van a pakliban".

- A gyerekek megszületésével eljön az idő, amikor már túl nagy lenne az ár, amit fizetni kellene. Az a visszafogás idôszaka lesz.

- Ám a jelenlegi befektetési idôszaknak is vannak hosszabb távú kockázatai: az egészség megromlása, illetve - különösen a lányoknál - a harmonikus párkapcsolat kialakításnak a nehézsége (és ezáltal a családalapítás elmaradása).

Valahogy így néz ki tehát a megkérdezettek általános karrierstratégiája, amit tudatosan fel is vállalnak.

„Hogy az anyagi biztonságot megteremtsem magamnak, 3-5 évig hajlandó vagyok mindent feláldozni. Ha azt mondják, hogy 24 órából 20-at dolgozzak le, és ezért meg vagyok fizetve, és látom, hogy a munkámnak eredménye van, gyarapodok belóle, akkor hajlandó vagyok kihajtani magam 3-5 évig. Utána egy nyugodtabb életre állok át. Tudom, mit adok fel érte, nem azt mondom, hogy a családomat feladom, de vállalom, hogy kevesebbet foglalkozom velük, de óértük csinálom." (13)

„Ha az ember nem akarja, hogy apuka tolja a szekerét... Persze, valamit valamiért. Idóból nagyon sokat elvesz, túlóra, hétvége, plusz az utazgatás.... Bevállalnám az elsó 15 évben biztos. Mert mikor máskor pörögne az ember, 40-50 évesen nem fogok. $A z$ ember próbálja addig kihajtani, amit lehet, vagy kicsit többet. Ez alatt lehet megalapozni a sikert, az egzisztenciát.

Nincsen választási lehetôség, tehát mondhatom azt, hogy én ennyit nem vállalok el, de akkor nem kapok munkát. Van, aki elvállalja, mert a cégnek ez az érdeke, hogy nem fizetik meg a túlórát. Amennyit tudnak, kiszednek belóled. Minél korábban jössz, annál többet bírsz, annál jobban teljesítesz. A huszonéves emberek nagyjából mindent kibírnak, és a cégek erre épitenek." (1)

A fiatalok úgy tekintik, létezik egyfajta pszichológiai szerződés köztük és a szervezet között: a cég most többet várhat el tőlük, mint a formális munkaszerzôdés alapján lehetne, viszont ezért olyan karriert kínál a fiataloknak, ami lehetôvé teszi az elképzeléseiknek megfelelő egzisztencia megteremtését. Kérdés persze, hogy ez mennyire egyértelmú és kétoldalú szerződés. Különös tekintettel a határidốkre és a kifizetések mértékére vonatkozóan. Az a gyanúnk, hogy a szervezetek inkább a lehetôséget kínálják fel, és valószínúleg hosszabb távra vonatkozóan, míg a fiatalok természetes következménynek tekintik és hamarabbi „,kifizetést” várnak.

A témával kapcsolatban mindenesetre bizakodóbban nyilatkoznak a még a tanulmányi fázisban lévoók, akik természetesnek tekintik ezt a múködésmódot. Azok, akik már ilyen körülmények között dolgoznak, sötétebb színekkel festik meg, hogy valójában mit is vállaltak be, mit jelent a folyamatos 10-12 órai munka. A cégek döntő többsége ugyanis szemlátomást jelentôsen belép a magánidốbe is a munkával. Elsôsorban este, de idônként hétvégén is. Több megkérdezett állítja, hogy munkán túl egyszerúen másra nincsen sem ideje, sem energiája. Feltúnố az is, hogy fiatal koruk ellenére meglepően sokszor kerülnek elő a betegség, kimerültség, kiégés fogalmai.

A túlhajszoltság kezelése pedig leggyakrabban a felhalmozódott gốz kiengedésében ki is merül. Mindenesetre úgy túnik, hogy önmagában a nagy munkaterhelés még nem jelent óriási problémát. Együtt tudnak élni vele, úgy látják, hogy ez megéri nekik. Az egészségükre vonatkozó kockázatok is kevésbé a mában, inkább hosszabb távon jelentkeznek, amiról a mindennapok pörgése könnyedén eltereli a figyelmet.

„Én is járok toborozni, elmondhatom, 12 órát kell dolgozni. Abba úgysem tud belegondolni senki, milyen heteken keresztül 12-14 órát dolgozni. Azt nem tudod meg, amíg nem tapasztalod meg, hogy nem tudsz felkelni, olyan fáradt vagy. Annak idején, amikor megkérdeztek bennünket, könnyen mondtuk, 16 óra, meg egész nap." (9)

„Látjuk, hogy valaki hamar kiég, beteges, mert stresszel, ideges, rosszul van. Vannak ilyenek, lehet, hogy ez multis sajátosság. Ez komoly harc. A fönököm mindig azt mondja, stressz ellen két jó dolog van,: egyik az ivás, másik a sport. Mindkettót úzöm. Tóle tanultam a kezelni a dolgokat." (3)

Bár fárasztónak, kimerítőnek érzik ezt a munkamódot, mégis valahol ez a természetes számukra, ez inkább egyfajta költség, semmint áldozat a karrierjük érdekében. Kézzelfoghatóbb probléma, és már rövidebb távon is jelentkező áldozat számukra a családalapítás, illetve már magának a párkeresésnek a nehézsége, akár elmaradása is.

A már dolgozó csoportokban egyetértettek azzal az általános közvélekedéssel, miszerint a multi cégeknél dolgozók, és különösen a lányok körében magasabb a 
szinglik aránya. A párkapcsolat kialakításának és megerôsítésének az ideje a tanulmányok idôszaka, ezután a pályakezdés a túlélés periódusa lesz. Akinek addig nem sikerült stabil kapcsolatot kialakítania, annak nehéz dolga lesz a napi 10-12 óra munka közben. Ezt azonban, ha nem is kívánatos, de természetes dolognak tekintik. „Most a munkahelyemen kell hogy bizonyítsak, nem a magánéletben", egyértelmúen ez a jelszó.

„,Mindenkinek megvolt a párja, mire idekerült. Senki sem ismerkedett meg az alatt az idôszak alatt, amióta itt dolgozik. Pedig lassan két éve itt vagyunk, ez elég sok idő. Nem lehet, fóleg úgy azt is nehéz néha az ember párjával megértetni, de hát mit tudtok ennyi ideig csinálni.

Az egy dolog, hogy mindenkinek a párja megérti. Szereted csinálni, látja. Mondod a hátrányait, nem arról van szó, hogy nem érti meg. Hétköznap nem tudsz programot szervezni, hétvégén alszol, akármennyire próbál megérteni, egy idố után visszájára fordul a dolog." (9)

Még elôrébb tekintve a tervek szintjén mindenki egyformán állítja, hogy hosszabb idôtávon a családot senki sem akarja áldozni. Egyfajta váltás lebeg a szemük előtt, amikor is megfordul a jelenlegi jelszó, és már a családi/magánélet lesz a fontosabb, nem a munka világa.

A családtervezésnek csak erre az oldalára koncentrálva azt gondoljuk, hogy tervezni könnyebb, mint megtenni. Nyilván nehéz kiszállni egy olyan életmódból, amibe a kezdetektôl beleszocializálódott valaki, aminek érti a logikáját, és amiben sikeres. Nehéz lehet azt is megvalósítani, hogy kevesebbet teljesítsen, nyújtson, mint addig. Ezt kevés szervezet fogadja el, különösen a tehetséges emberek esetében, akik az addigi teljesítményük elismeréseként egyre nagyobb felelősségeket és feladatokat kapnak. Ezek az elismerések, akár előrelépések pedig nagy valószínúséggel éppen abban a 4-6 év múlva bekövetkező idôszakban jönnek majd, amelyre pedig a visszafogást, a családi élet felé való fordulást tervezik a jelenlegi pályakezdók.

Az azonban megállapítható, hogy hosszabb távon senki sem akarja folytatni ezt az áldozathozatalon alapuló múködésmódot. Ezt inkább egy rövid távú üzletkötésnek gondolják. Elgondolkodtató ugyanakkor, hogy ốk ebbe a szélsőségesnek tekinthetô helyzetbe szocializálódnak bele, erre a típusú munkavilágra alakítják ki a kompetenciáikat, értelmezési kereteiket, feltehetô, hogy egy idô múlva ez lesz számukra a természetes „munkavilág”. Ugyanakkor érzelmi oldalról folyamatosan jelen van egy negatív helyzetértékelés - ez egy kockázatos, veszélyes, nem egészséges életmód, valamint az átmenetiség jellege: ezt csak azért csinálom, hogy késóbb más lehessen. Az biztos, hogy ez nem egy harmonikus, kiegyensúlyozott modell. Sok belsố munkát igényelhet ennek a fenntartása.

\section{Mi a hosszabb távú igényszintjük?}

Az eddigiekból többször kiderült, hogy az anyagiak, az egzisztenciateremtés fontos szerepet játszanak a megkérdezett fiatalok választási szempontjaiban és terveiben. A csoportokon az anyagi célokkal kapcsolatban az általános hívó szó a középréteg, felsôközépréteg volt. Vagyis az igényeiket természetesnek érzik, állítják be, sokan kihangsúlyozzák, hogy nem a luxus, vagy a harácsolás a cél. Amikor a csoportokon elhangzott, hogy a megfelelő életszínvonal megteremtése érdekében dolgoznak, akkor feltettük nekik a kérdést, hogy fogalmazzák meg konkrétan, hogy mit jelent nekik ez a színvonal. A válaszok tartalma, de legtöbbször még az egyes elemek elhangzásának a sorrendje is kísértetiesen egyforma volt, függetlenül attól, hogy már dolgoztak vagy még tanultak, vidékiek vagy fóvárosiak, bölcsészek vagy közgazdászok.

- Az alapmondat: „Ha bemegyek egy boltba, meg tudjam venni, amit akarok. Ne érdekeljen, mennyibe kerül.” (A mondat leggyakoribb másik változata: „Meg tudjam venni, amit a gyerek kér.")

- Legyen megfelelően nagy saját lakás, ha lehet ház, ha lehet jó környéken, zöldövezetben.

- Legyen kocsink, és lehetôség szerint a páromnak is.

- Alapértelmezésben el tudjak menni évente kétszer jellemzően külföldre - nyaralni. Egyszer télen síelni, egyszer pedig nyáron üdülni. (Ez esetben a „sziget” a kulcsszó, a minőség kifejezője.)

- Tudjak úgy gyereket vállalni, hogy az anyagi megfontolások ne hátráltassanak ebben. (A gyerekkel kapcsolatban jellemzően még megjelenik az is, hogy a késôbbiekben ne okozzon gondot az ó külföldi tanulmányainak a biztosítása.)

A következő aláfestő idézetek esetében mindig az volt a kérdés, hogy mi az elvárt életszínvonal.

„Nyaralás, oda, ahová én szeretnék, nem érdekelne, hogy mennyibe kerül. Ne kelljen a boltba megnézni, mennyibe kerül a tej, tejföl, ha családom lesz, meg tudjam a gyerekeimnek adni, amit elvárnak." (2) „Budán egy családi házban, társasházban, és ha elmegyek vásárolni, ne azon kelljen a filléreket számolgatom, hogy melyik kenyeret vagy joghurtot vegyem meg, amelyik olcsóbb, hanem amelyik tetszik, és hogy el tudjak menni külföldre, utazni." (1)

„Szeretnék lakást, kocsit, azt szeretném, hogy annyi pénzem legyen, ha elmegyek egy étterembe, akkor meg tudjam rendelni, amit éppen enni szeretnék." (10)

\section{VEZETÉSTUDOMÁNY}




\begin{abstract}
„Hogy az ember nyáron úgy el tudjon menni, hogy nem februártól gyújtögeti, hanem júliusban kezd el figyelni arra, hogy augusztusban el tudjon menni nyaralni. Gyerekvállalás: ne az legyen, hogy most valahogy biztonságosan felnevelni a gyerekeket, amennyire lehetóség van. Meg annyi gyereket vállaljon az ember, amennyit el tud tartani, ez ne legyen ilyen anyagias." (/)

„Felsó középosztály, jól áll, nincsenek problémái, legyen két autó, normális családi ház, el tudjak menni nyaralni, a gyerek el tudjon menni egy évre külföldre." (21)
\end{abstract}

Az utazás, nyaralás témájához fúznénk egy megjegyzést. Úgy látjuk, hogy az utazás sok esetben nem egyszerúen a pihenésról szól, hanem önértéke van. Megjelenik benne a szabadság, függetlenség, a nem itt vagyok a „taposómalomban” érzése. Azaz az „ott lenni” mellett a „nem itt lenni” gondolata legalább annyira fontos.

Ók maguk ezeket az igényeket teljes mértékben természetesnek, gyakorlatilag alapszintúnek kezelik. Többször is a szüleikhez képest fogalmazzák meg ezt a színvonalat, utalva arra, hogy tulajdonképpen csak ugyanazt akarják, illetve folytatni akarják azt, amiból érkeznek. Ráadásul, ha a fiatalon befutott 90-es évek elején indult generációra tekintenek, akkor sem túnnek kiugrónak az elvárásaik.

Ugyanakkor, ha a tágabb társadalmi képet vesszük, akkor ez az életforma csupán a felsố $10 \%$-ot, esetleg még kevesebbet jelent. Vagyis kifejezetten felfelé, és a korábbi munkaerô-piaci, gazdasági viszonyok között indult korosztályokhoz viszonyítva határozzák meg az igényszintjüket, ami könnyen válhat túlzóvá a jelent tekintve. A megcélzott 3-5 éves idôtávot azonban mindenképpen irreálisnak lehet tekinteni.

Ennek az elsősorban fogyasztói szerepből („,megvehessem azt, amit akarok") megfogalmazott, és alapvetôen felfelé viszonyított elvárásnak, véleményünk szerint, könnyen lehet egy végtelenített szalagon való taposás a végeredménye. Az, hogy mit akarok megvenni a boltban, mit tekintek természetesnek, illetve luxusnak, nagyon könnyen változhat, különösen, ha a referenciacsoportom is változik. (Eleinte az évfolyamtársaim, aztán a munkatársaim, aztán a vezetôtársaim stb.) Ami ma luxustermék, az holnap természetes, és közben nem is érzékeljük, hogy változik a igényszintünk. Ugyanez a helyzet a kocsi típusával, a lakás nagyságával és helyével is.

Vagyis nagyon erôsnek ítéljük meg az általuk ,,belepörgés"-nek nevezett jelenség lehetôségét. (Korábbi, a fiatal vezetôkkel foglalkozó kutatásunkban azt találtuk, hogy az évi 20-40 milliót kereső́k is természetesnek, [felsô-] középosztálybelinek tekintik életmódjukat, és másokat tekintenek gazdagnak és luxusfogyasztónak. A gyerek- születés pedig kifejezetten megerósítette az egzisztencia fenntartásához kapcsolódó motivációkat. $)^{5} \mathrm{Az}$ anyagi motiváció ritkán hagy alább, vagy sorolódik hátrább.

A fiatalok gondolkodásmódján az is látszik, hogy oók elsősorban még csak a kívánt szintig eljutásban, megszerzésben gondolkodnának, és még nem látnak bele a megés fenntartás szükségességébe. Vagyis mintha egy statikus célállapotot érzékelnének, ami után le lehet állni.

\section{Családtervezés: férfiszemmel}

A családtervezéssel kapcsolatos kérdéseknél külön elemezzük a fiúk és lányok válaszait. Erre azért van lehetôség, mivel már a fókuszcsoporton is külön kérdeztük őket erról a témakörról.

Előrebocsátva és összefoglalóan elmondható, hogy a fiúk válaszai a tradicionális szerepfelfogást tükrözik. Mindez a következő alapmondásokban foglalható öszsze, amelyek mintegy ki is jelölik az üzleti szervezetben karrierre készüulő férfi útját:

- „Nekem kell a család egzisztenciáját biztosítanom. Jó, ha a párom segít, de erre egyedül is képesnek kell lennem."

- „Ha gyerekem születik, akkor olyan helyzetet kell tudnom teremteni, hogy a párom sokáig otthon maradhasson, akár végleg az anyai szerep betöltése mellett dönthessen."

- „A párom, ha akar, dolgozhat, de azért ne legyen karriermániás."

- (Végül a ki nem mondott, de beleértett mondás.) „Ha akarom, akkor lesz párom. Párt találni nem nehéz." „Én úgy képzelem el: a feleségemnek nem kell dolgoznia, gyerekre vigyáz, otthon van, nem kell karriert befutnia, nem muszáj mindent bevállalnia. Szeretnék annyit keresni." (14)

„Nem akarom azt mondani, hogy a feleségem otthon maradjon, gyereket pelenkázzon, fó́z, mos, takarít. De nem bánnám, ha amíg a gyereknek szüksége van rá, otthon marad. Meg nincs az a dilemma, hogy drágám, nem akarom a gyereket, mert karriert építek. Szeretnék egy olyan életszínvonalat, hogy egyedül el tudjak tartani egy családot. Nem szeretnék elválni, szeretném, ha a feleségemnek inkább a család lenne az elsódleges, karrier a család után, mert amikor van egy 3-5 éves gyerek, akkor is el lehet kezdeni karriert épiteni." (7)

A férfiak útja tehát kemény - sokat kell dolgozniuk, és értelmezésük szerint rajtuk van elsősorban az egzisztenciateremtés terhe -, ám ez egy magától értetődő, maguk és környezetük számára is természetes szerep. Ráadásul, ha vezetôként, a munkában sikeresek lesznek, akkor ez pozitívan hat ki a családban betöltött szerepükre is, hiszen kiválóan teljesítették feladatukat. Persze ebbe a logikába is beépül egy feszültség, sokat 
kell dolgozni a családért, és ezért nem lehetnek velük, de terveik szerint ez kezelhetô probléma.

A mondataik még egy előfeltevésról árulkodnak. A gyerekvállaláshoz szükséges a megfelelően megalapozott egzisztencia. Teljes mértékben a racionális családtervezés hívei. Egyetlen olyan véleményt sem hallottunk, hogy valaki minél korábbra tervezi a gyerekek vállalását. Szerintük ehhez szükséges elóbb egy biztonságos háttér.

\section{Családtervezés: nôi szemmel}

A lányokkal lefolytatott beszélgetések elemzése már nem ilyen egyszerú és egy irányba mutató. Sokkal több a dilemma, és ennek megfelelően érzelemtelibbek a megnyilvánulások:

- „Mikor mehetek úgy el szülni, hogy az ne tegye tönkre a karrieremet?"

- „Gyerek mellett lehet-e, s milyen karriert folytatnom?"

• „Mennyi idő után lehet/kell visszajönni a szülés után?”

- „Mit várhatok a páromtól?"

- „Hogyan ne legyek kiszolgáltatva a páromnak?”

- „Hogyan lesz párom?”

A fenti dilemmák természetesen nem függetlenek egymástól, és megfigyelhetô néhány jellegzetes minta, amelyek mentén a várakozásaik szerint a múködtethetô megoldások kialakulnak. A legjellegzetesebb ilyen csoportokat mutatjuk be, a tapasztalatunk szerinti gyakoriságuk sorrendjében, kezdve a legnépszerúbbel:

- Vannak, akik kemény munkát terveznek az elsố 3-5 évre, hogy utána legyen elismertségük és alkupozíciójuk - már bizonyítottak -, így a gyerek után visszatérhessenek. Ez teszi számukra lehetôvé a visszatérést megfelelő pozíciókba. Jellemzóen azt gondolják, hogy nem szabad 3 évet otthon maradni, legfeljebb egy évre lehet kiszállni negatív konzekvenciák nélkül. A cég felé is jobb üzenet ez, de ók maguk sem akarják feláldozni a karriert a gyerekért. E nók esetében tehát a család egyfajta - rövid - karrierszünetként értelmezhetô.

„Így is, úgy is visszavárnak, nem kérdés ez a cégnél, csak az, hogy ugyanolyan pozícióba kerïlj, hogy tudj továbbfejlódni a karriered szempontjából. Pár hónap után sokkal egyszerúbb visszajönni, ez nem csak cégtól függ, én nem szeretnék két évet kiesni a munkából, maximum fél évet, ehhez olyan ember kell a másik oldalon, aki ezt el tudja fogadni." (3)

- A második stratégia is a munkára helyezi a hangsúlyt az elsố években. Itt azonban más motivációk kerülnek előtérbe: kiélvezni ezt az oldalát is az életnek, megmutatni mire képesek. Ezután jöhet a családalapítás, gyerekvállalás, ami azonban e stratégia mentén egy új életforma beköszöntését jelenti. Ôk szeretnének hosszú ideig, amíg csak lehet otthon maradni a gyerekekkel. Ezek a nôk azt gondolják, lehet, hogy késóbb is fognak dolgozni, de már a családnak alárendelten, esetleg más szakmában is. OOk tehát alapvetốen karrierváltásban gondolkodnak, és a karrierjüket egyértelmúen alárendelik a családnak, az anyai szerepüknek, legalábbis a gyerekek kiskorában. Többen is megemlítik, hogy késóbb újra lehet majd indítani a karriert. (Mint látható, ez a minta jól illeszkedik a legtöbb fiú által elképzelt, elvárt nôi magatartáshoz.)

„Ha gyereket szülök, biztos otthon maradok, az több év kiesés lesz az aktív munkaerópiacból. Utána jó lenne, ha 6-8 órás munkát vállalnék, nem 8-10, hanem 6-8, hogy tényleg a gyerekeimre oda tudjak figyelni. Nemcsak én, nyilván örülnék, ha a férjemnek is olyan munkája lenne, hogy nem csak este 10-kor látnák a gyerekek meseolvasáskor, hogy tudjunk családi életet élni." (16)

„Én mindenféleképpen szeretnék nagyon sok idốt tölteni a gyerekekkel, amíg lehet, otthon maradni velük. Ha már el kell mennem dolgozni, maximum 4-6 órában tudom elképzelni, de hogy 8 órában dolgozzak, mellette figyeljek annyit a gyerekekre, meg a háztartásra, amennyi szükséges - azt nem fogom tudni megoldani." (20)

- A harmadik csoport nem elsôsorban a gyerekvállalásról, hanem a párkapcsolatról való gondolkodásában különbözik. Az ô alapmondatuk így hangzik: „Magamra számíthatok.” Ốk azt gondolják, hogy képesnek kell lenniük arra, hogy akár férfi nélkül is egzisztenciát teremtsenek, illetve ha elválnak, akkor se legyenek kiszolgáltatva egyedül vagy gyerekekkel. Jellemző módon ezzel a típussal már az interjúkon is jól összevitatkoztak a fiúk. Támadónak érzik ezt a hozzáállást, úgy érzik, hogy ók családpártiak a maguk egzisztenciateremtő hozzáállásával, a lányok viszont ezt függősségbe kényszerítésnek érzik. Azt gondoljuk, hogy itt pedig nem férfigyúlöloókról van szó. Ôk tudatosan önállóságra törekednek, szemükben ez lehet aztán egy kiegyensúlyozott párkapcsolat alapja. Kétségtelenül elvetik a hagyományos férfi/nói szerepmegosztást, de például jól tudnak illeszkedni a fiúknál alternatívnak tekintett modellhez, ami szintén az egyforma felelôsségvállalásra építene, például a gyereknevelés kapcsán.

„Teljesen biztos, addig nem szülök gyereket, amíg egyedül nem tudom eltartani, mindegy hogy van férjem, nincs férjem. Mi van, ha jön egy 20 éves szóke, én meg oda kerülök, hogy ott vagyok x gyerekkel, tíz éve nem dolgoztam, mert azóta otthon ülök, akkor mit kezdek magammal. Attól szeretheti még a család-

\section{VEZETÉSTUDOMÁNY}

XXXVIII. ÉVF. 2007. 2. SZÁM 
ját az ember, hogy nem akar otthon maradni a gyerekkel. Egy nó számára az nem elóny, hogy te megengeded neki, hogy otthon maradjon." (15)

„Biztonságot szeretnék elérni, a mai világban nem akarok férfire számítani. Úgy építem fel az én kis életemet, hogy ha ott maradnék egy-két gyerekkel egyedül, tudjam azt az életszínvonalat tartani férj nélkül. Ehhez az kell, hogy karrier legyen... Csak saját magamra számíthatok, a másik emberre nem akarok úgy számítani, hogy ki legyek neki szolgáltatva. Olyan társat akarok, aki társ a szó szoros értelmében. Az ó világát nem tudom kiszámítani, ezért saját magamnak fogom megteremteni a biztonságot." (7)

A fentiek alapján kijelenthetô, hogy általában nagy bizonyítási kényszer múködik a nőkben, hiszen számukra ott van egy erős idókorlát, nekik 4-5 év alatt kell olyan helyre eljutni, ami a maguk önképének is megfelel, illetve szülés utáni visszatérésre is lehetőséget ad.

A fent ismertetett minták közös jellemzője, akárcsak a fiúknál, hogy a gyerekvállalás ideje egyértelmúen eltolódik a 29-30 évek idôszakára, már eleve a tervek szintjén is. Nem találkoztunk olyannal, aki azt mondja, hogy gyorsan szülne gyerekeket, inkább a másik véglet emlegetésére lehet példát találni: „35-be jó lenne beleszorítani." A gyerekszülés kapcsán egyébként, ha nem is abszolút igényként, de többször is megjelent az otthoni munka és a részmunkaidô, mint elvárt támogatás.

A családtól függetlenül is megjelent néhány közös téma a nói hozzászólásokban. Létezik egy mindenki által osztott nagy közös félelem és hiedelem, miszerint az állásinterjún megkérdezik a gyerekvállalást, amit le kell tagadni. Kiderült ugyan, hogy konkrétan nem kérdezték meg egyiküktól sem, de mindegyikük tudni véli, hogy ez a szokás. Ennek kapcsán megjelenik az a hiedelem is, hogy a fiúkat jobban preferálják az állásinterjún. Mindez csak megerősíti bennük, hogy ók hátrányosabb helyzetben vannak karrierszempontból.

„Biztosan nézik, hogy nó vagy. Most voltam egy állásinterjún, az ötödik fordulón azért nem esett rám a választás, mert a másik jelölt egy fiú volt. És ốt választották. És ahol egy fiú és lány maradt, akkor a fiú nyert. Egyetértek, mert van két azonos korú ember, akkor belegondolok, hogy ez a lány szülni fog, mi meg belefeccelünk egy csomó energiát. Akkor legyen inkább a fiú. Lehet hibáztatni óket ezért, ez diszkrimináció, szemétség, de ez van.” (1)

„Az állásinterjún megkérdezik a gyereket, és le kell köpni a földre, és azt mondod, gyerek, na ne vicceljen. Ebbe megy el a dolog." (17)

Ez kiderül a következő önkorlátozásból is: a felsô vezetôi karrierrôl általában lemondanak a nôk, arról beszélnek, hogy az nem egyeztethető össze a gyerekekkel.
Legfeljebb a középvezetói szint az, ami múködóképes. Látszik ugyanakkor, hogy nagyon számon tartják a saját cégükön belüli vezetố nốket, különös tekintettel a gyerekesekre. Ezek a minták jelentősen befolyásolják a hitüket, hogy mire lehetnek képesek a cégnél, illetve, hogy mit várhatnak el, amikor ók is a gyerekvállalás korszakába jutnak.

\section{Hazai eredmények: Generációs jellemzók}

A kutatási eredmények elemzését egy összefoglaló jellegú témával zárjuk. Különböző kérdések mentén azt veszszük szemügyre, hogy azonosíthatók-e olyan generációs sajátosságok, amelyek jelentósen megkülönböztetik a most munkába lépó korosztályt a korábban érkezettektôl.

\section{Generációs $\boldsymbol{k}$ ségek}

A kérdőívben felsoroltunk 34 személyes tulajdonságot, és azt kértük, hogy válasszanak közülük ki 5-5-öt, amelyek elsősorban a saját, illetve az elôttük haladó, 30-40 éves generációra jellemzőek. (A szakirodalom óket tekinti klasszikusan az X-generációnak, itthon pedig megegyeznek a rendszerváltozás után, a 90es években a munkaerópiacra lépett korosztállyal.) Az eredményt mutatjuk be a 4. táblázatban.

4. táblázat

Egyes tulajdonságok választásának gyakorisága

\begin{tabular}{|c|c|c|c|}
\hline $\begin{array}{c}\text { Saját korosztály } \\
\text { jellemzése }\end{array}$ & Gyak. & $\begin{array}{c}\text { Elózó́ generáció } \\
\text { jellemzése }\end{array}$ & Gyak. \\
\hline Anyagias & 81 & Családorientált & 82 \\
\hline Nyitott & 58 & Felkészült & 50 \\
\hline Elégedetlen & 51 & Óvatos & 49 \\
\hline Független & 45 & Anyagias & 43 \\
\hline Individualista & 40 & Tudatos & 41 \\
\hline Törtető & 38 & Megbízható & 39 \\
\hline Tudatos & 36 & Magabiztos & 38 \\
\hline Tág érdeklődési körü & 34 & Elégedetlen & 37 \\
\hline Vállalkozó kedvú & 33 & Bizalmatlan & 34 \\
\hline Bizalmatlan & 29 & Vállalkozó kedvú & 27 \\
\hline n.w. & $\cdots \cdots$ & ………… & $\ldots \ldots$ \\
\hline Önfeláldozó & 6 & Közösségorientált & 7 \\
\hline Érzékeny & 6 & Etikus & 6 \\
\hline Szerencsés & 3 & Idealista & 6 \\
\hline Családorientált & 3 & Szerencsés & 6 \\
\hline Hagyománytisztelő & 3 & Sokoldalú & 6 \\
\hline Etikus & 0 & Informális & 5 \\
\hline Kiegyensúlyozott & 0 & Nagyképú & 3 \\
\hline
\end{tabular}


Az eredmények azt mutatják, hogy eltérô szavakkal jellemzik a különböző korosztályokat. A saját generáció jellemzése egy elszánt kemény, versengố, elsôsorban a saját és anyagi céljaiért küzdő személy arcát mutatja. A szakirodalomban yuppiként emlegetett, karrierista, fogyasztásorientált, a maga sikerével foglalkozó réteghez áll közel. Jól illeszkedik ehhez a képhez az, hogy senki sem gondolta, hogy az etikusság jellemzô lenne a saját korosztályukra. A szakirodalomban ismerôs ez a kép, ám meglepó, hogy ezeket a jellemzóket éppen a korábbi, X-generáció kapcsán szokták felemlegetni.

Ha figyelmünket a lista aljára összepontosítjuk, a legkevesebbet kapott jellemző szavak listája arra a kérdésre ad választ, hogy „Kik nem vagyunk mi?”: önfeláldozó, érzékeny, szerencsés, családorientált, hagyománytisztelő, etikus, kiegyensúlyozott. Feltűnő, hogy csupa pozitív jelző, és inkább a közösség és kapcsolatok felé forduló ember képét érzik nagyon távolinak maguktól.

Mi még a saját magukról alkotott kép kettősségére hívjuk fel a figyelmet. Egyfelól pozitívan is lehet értelmezni a lista élén álló, leginkább jellemzô tulajdonságokat, hiszen ott szerepel a nyitottság, a vállalkozó kedv és a tudatosság, másfelól azonban az anyagiasság kiugró aránya, valamint az individualizmus és a törtetés magas említése egyértelmúen negatív értékekre utalnak. Egyfajta cinizmus, a gátlástalanság nyílt felvállalása jellemzi ezt az önképet.

Az előttük járó generáció jellemzése már inkább pozitívabb, bár az sem egyértelmúen. Egy lelassult, a család felé forduló, és a pozíciók megốrzésére ügyelô csapat képét mutatja. Ebben a képben is vannak azonban belsố feszültségek, mint például a megbízható, de megbízhatatlan jelzók egyformán gyakori említése, valamint az anyagias és az elégedetlen szavak sem pozitív hangzásúak. Számunkra meglepő, hogy ilyen kevesen választották a szerencsés jelzốt, pedig ez a generáció volt, amely a rendszerváltás környékén számára nagyon kedvező munkaerópiacra léphetett ki, és fiatalon futhatott be gyors karriert.

\section{Generációs önkép}

A fókuszcsoportokon elhangzottakat elemezve szembetúnő, hogy amikor saját magukat jellemzik, mennyire ritkán beszélnek belső, személyes dolgokról. $\mathrm{Az}$ öndefiníciójuk inkább a külső körülmények befolyásoló hatásából származik. Amilyen a világ, annak megfelelóen kell múködnünk, mondják. Ebból kiindulva, amikor magukat jellemzik, sokszor inkább a körülményeiket jellemzik.

Meglepő jelenség, hogy a külsố trendeket, amelyekkel a saját korosztályuk jellemzőit leírják, jobbára csak az elmúlt pár évnek tulajdonítják. Pedig, ezek már jó ideje jelen lévő hatások, és valószínúleg már az elôzô korosztály is a saját idejében lévoónek, magára hatónak élte meg ezeket. Ilyen például a felgyorsulás, az infokommunikációs technológiák megjelenése, a világ kinyílása. Persze, az mindenképpen más, hogy a 30-asok életében ezek a hatások felbukkantak, és aztán részévé váltak, a huszonévesek számára pedig jobbára már ezek jelentették a természetes szocializációs környezetet.

Nyilván jelenlegi helyzetükból is kiindulva, sokat foglalkoznak a felsôoktatás megváltozásával, és ennek karrierlehetôségeikre gyakorolt hatásával. Összességében úgy gondolják, hogy rosszabbul jártak. Az oktatás jellege is kedvezőtlenül változott, a tömegoktatás szerintük rosszabb színvonallal jár, és rontja a munkaerő-piaci esélyeiket is. Úgy érzik, korábban a kevesebb hallgatót magasabb színvonalon oktatták. Ráadásul a választási lehetôségek, a kreditrendszer megjelenése, a tanárok stílusának demokratizálódása is csak lazította a képzés kereteit, a többség ezt csak az elvárások lazítására használta. A képet csak némileg árnyalja az a hatás, miszerint a nagyobb szabadság nagyobb önállóságra, felelősségvállalásra is nevelte ôket.

„Sokkal kevesebben esnek ki a képzésból, csak az nem fejezi be, aki nem akarja, elóbb-utóbb mindenkinek lesz diplomája. Tíz éve felvettek 50-60 embert, aki ha nem teljesített, nem kapott diplomát. Most diplomagyártás van, azt hallani, hogy „csak legyen egy diplomád". Régebben még presztízse volt, meg kellett becsülni és küzdeni kellett érte." (2)

„Közgazdászokon marhára meglátszik az, hogy úgy termelik ki óket, mint egy gyárban. Öt év alatt nem volt tanár, aki tudta volna a nevemet. Bementem a tanulmányi osztályra, X.Y. vagyok. Az nem érdekel, mi a Neptun-kódja?" (17)

A külsố befolyásoló tényezốk közül a leggyakrabban említett hatás mégis a munkaerópiac megváltozása. Minden jelentôsebb, általuk érzékelt különbséget szinte ennek akarnak betudni. Ide fut ki a tömegoktatás legkedvezőtlenebb hatása is. Vagyis manapság többen mennek ki egy kevesebb lehetôséget kínáló munkaerôpiacra, ami egyértelmúen erôs versenyhelyzetet generál számukra. A versenyben lenni fontos alapélmény számukra, és ennek következtében sokkal hamarabb megjelent életükben a teljesítményszemlélet, mint korábban.

„A 30-40 éveseknek lényegesen könnyebb volt munkát találni, mert nem tízezrekkel együtt mentek a munkaerópiacra, hanem elit réteg volt, aki egyetemre, fóiskolára bekerült. Nem voltak olyan telítettek a sikerszakmák, sikerpályák: közgazdász, jogász. Most fordítva van, szakmunkásban van hiány, informatikusok, mérnökök kapják a jó állást, a jó pénzt." (15)

\section{VEZETÉSTUDOMÁNY}


„Az unokatesóim, akikból ki tudok indulni. Megvolt a lehetôségük, volt két nyelvvizsgájuk, onnantól bárhol el tudtak helyezkedni. Most két nyelvvizsgával jön ki az ember a gimiból. Nálunk az osztályunkban 35 fóból volt negyven valahány nyelvvizsga, több mint a felének kettó volt." (1)

A külső környezet jellemzése során visszatérő elem, és egyben a legfőbb jó hír a kinyílás. Változott az ország, és az EU helyzete, ez lehetôségeket kínál számukra. Nyitottabbá vált a világ, ez fontos alapmondás és alapélmény számukra. Rövidebb távon ez főleg a külföldi ösztöndíjlehetőségekben nyilvánul meg, hosszabb távon pedig a külföldi munkavállalásra való nyitottságot eredményezi.

„A barátaim egyharmada már élt hosszabb távon külföldön. Az, hogy nem tudom felhívni, mert Japántól kezdve a világ különbözó pontjain élnek, ez nem szempont, ez számomra normális.” (15)

„Nekünk sokkal könnyebb, nyitottabbak a lehetôségek. Ha valaki külföldre akar menni, annyi lehetôség van. Ki is mennek külföldre, akik valamit el szeretnének érni." (20)

A környezetból fakadó versenyhelyzet és bizonytalanságra való reakcióként két fontos tulajdonság visszhangzik többször is: rugalmasság és tudatosság.

A rugalmasság egyfelól sokuk fontos elvárása a munkaadóival szemben - lásd a döntési szempontokról írottakat -, másfelől saját múködésüket is jellemzi. Mennyit kell dolgozni, hol kell dolgozni, milyen keretek között kell dolgozni? Mi történik akkor, ha valamiért el kell hagynom egy munkahelyet? Csupa olyan kérdés számukra, amihez úgy érzik, hogy a korábbi korosztályoknál nagyobb nyitottsággal közelednek. Persze felvethetô, hogy valószínúleg ez a hozzáállás mindig is jellemző volt a fiatalabb, még nem családos munkavállalókra. Ugyanakkor az is igaz, hogy a mai világban valóban sokkal többféle lehetőség merülhet fel, és időben is gyakrabban következnek be változások a munkakörülményeikben és azok tartalmában.

„A mi korosztályunk kifejlesztett egy napról napra életmódot. Persze, van takarékoskodás, elórelátás, de könnyebben elfogadjuk, hogy ha nem lehet tíz évre elöre gondolkodni. Nagyobb a bizonytalanság.

Ók abban éltek, nevelkedtek, hogy napi 8 órás munka. Szerintem, aki itt van, napi 4 órát dolgozik az egyik munkahelyen, 4 órát a másikban. Ezek más, alternatív munkakörök. Ezt én jobban elfogadom, nekem nem fontos, hogy napi 8 órát egy munkahelyen gürizzek." (6)

A rugalmasság mellett a tudatosság vált alapvetô, néha kicsit szlogenszerú hívó szóvá, ami segíthet a bizonytalan környezetre való felkészülésben. Tudják, hogy ilyennek kell lenni, hallják, látják az ennek hiányából fakadó veszélyeket, például az elôtttük járók esetében. Nagyon sok téma kapcsán felhozzák a tudatosság szükségességét:

1. Pályaválasztás, munkahelyválasztás során, és arra való felkészülésben.

2. Munkaeró-piaci érték növelésében, olyan tapasztalatok gyújtésében, amelyek elônyösebb helyzetbe hozzák óket késóbb.

3. Munka és magánélet közti határtartás. Ez különösen inkább a jövőbeni célokra vonatkozik, amikor is lányok megállnának inkább alacsonyabb vezetôi szinten, vagy valami alternatív karriert is bevállalnának, a fiúk pedig oda akarnak figyelni, hogy mennyi ideig maradnak majd a munkahelyen.

4. A párválasztás, családalapítás/önállóság-függetlenség fenntartása olyan kérdésekké váltak, amelyek időben jelentôsen kitolódnak, így több idő jut a válogatásra, kísérletezésre, illetve egyszerúen a témához kapcsolódó érzések megérésére. Korábban már láttunk példát, az önállóságra törekvő nốk helyzetére is. Korábban az volt a természetes, hogy megházasodnak a fiatalok, gyerekeik születnek, aztán majd építenek egy egzisztenciát. Manapság az a természetes, hogy mindenki épít egzisztenciát, karriert, aztán majd megházasodnak vagy nem, és lesznek gyerekeik vagy nem. Ez utóbbiakra vonatkozóan születnek inkább tudatos döntések, vagyis egyáltalán nem magától értetődő lépések. Úgy véljük, hogy a párválasztás és családtervezés kérdéseiben mindenképpen kiemelkedően tudatosak a korábbi generációkhoz képest.

A sok-sok tudatosság példának ugyanakkor ellent is mondanak azok a történetek, amelyek a véletlenszerú sodródásokról, iskola- és munkahelyválasztásokról szólnak. A karriercélok kapcsán is jeleztük, hogy kevéssé tûnnek jól körvonalazottnak. Szóval a jövőbeni helyzetekre vonatkozó tudatosság szándéka érződik, de nem minden esetben túnik megalapozottnak. Végül is ugyanazt a mintát követik, mint az előttuik járó korosztály: Most be kell fektetni, majd késóbb tervezik a viszszafogást. Hogy miért gondoljuk azt, hogy nekik talán még kevesebb esélyük lesz ezt a határhúzást, visszalépést megvalósítani?

Éppen a korábban már említett versenyhelyzet miatt. Erốs elvárásokat, sok versenytársat érzékelnek maguk körül, és korábban kiderült, hogy karrier- és egzisztenciális célkitúzéseiket pedig a legmagasabb szintre helyezik. Ez a versenyhelyzet nehezen teszi majd lehetôvé a tervezett visszafogásokat, legalábbis azok számára, akik versenynek értelmezik a kereteket, és versenyben is akarnak maradni.

Hogyan lehet összefoglalóan jellemezni ezt az önképet? Kiindulásképpen megállapítható, hogy egy ra- 
cionális, a környezetból érkezố nyomásokra reagáló korosztály képe ez. Ugyanakkor egyértelmú, hogy a világképét végül is mindenki maga fogalmazza meg, az nem kívülról érkezik. Nem mindegy, hogy mit vesz észre a környezetéből, mihez akarja igazítani a magatartását. Ez a kifelé igazodás is egy belsố választás eredménye. Megváltoztatni a világot? Ilyen típusú gondolat fel sem merült a fókuszcsoportokon. Messze nem forradalmár alkatok. Semmiképpen sem valamilyen ideológiából, magasabb értékekból vezetik le céljaikat, múködésüket. Céljuk a személyes anyagi jólét biztosítása a későbbi családalapítás idejére, amihez sikeres karriert kell befutni. Individualista és materiális hozzáállás. Felpörgött a világ, bele kell tenned magad, hogy ne maradj le, sikeres legyél.

\section{Összefoglalás}

Itt az idő tehát, hogy megfogalmazzuk válaszunkat a kutatás egyik legalapvetőbb kérdésére. Létezik-e ma Magyarországon az ún. Y-generáció? A kérdés megválaszolása elő́tt érdemes tisztázni válaszunk ,helyi értékét”, azaz korlátozottságát és a vonatkoztatási körét.

Egyfelól a viszonyítási alap sem egyértelmú. Azaz azt sem tudjuk valójában, hogy külföldön van-e X- és Y-generáció, csupán a szakirodalom kijelentéseihez tudjuk viszonyítani saját eredményeinket. És mint erról a szakirodalmi összefoglalóban írtunk, ez a szakirodalom messze nem egységes sem a generáció létét, sem pedig jellemzóit tekintve.

Másfelól eredményeink hazai általánosíthatóságát a mintavételi stratégiánk és az adatgyuujjtési módszerünk is korlátozza. Mintánk kisméretú és elsősorban a gazdasági végzettségúekre koncentrál, továbbá inkább nagyméretû szervezetekben elhelyezkedett pályakezdók kerültek bele. Ennyiben inkább feltáró jellegú, mintsem a kutatási kérdésekre végleges pontot tevő eredményeket várhatunk.

Úgy gondoljuk azonban, hogy a mintavétel célzottsága, valamint a módszertanunk mélyfúrás jellege mellett a közvetlen célcsoportot illetően megbízható és hiteles kijelentéseket tehetünk, nyitottan persze a további elemzésekre és kritikákra. Következzenek tehát válaszaink!

Röviden összefoglalva, úgy gondoljuk, hogy jelenleg Magyarországon nincsen generációváltás, nem jelent meg egy a korábbitól jellegzetesen eltéró, határozott identitástudattal rendelkezó korosztály. Nincsen Y-generáció, sem azért mert nem tekinthetốk (új) generációnak, sem azért mert nem jelennek meg markánsan a szakirodalom által az Y-osoknak tulajdonított jellemzók.
Ezt a választ árnyaljuk a következőkben, mivel bizonyos tekintetben találhatunk változási trendeket, illetve egyes jellemzók esetében egyezéseket a külföldi Y-generációval, és minden bizonnyal van a korosztálynak egy olyan csoportja is, akit akár Y-generációnak is nevezhetnénk. A lényeg azonban az, hogy nem érzékelhetố generációs szakadás, korszakváltás, hanem a rendszerváltozás utáni jelentôs változások utórezgései zajlanak, az üzleti életben elhelyezkedôk számára akkor kialakult és jellemzővé vált életstratégiák és értékrendszerek finomodása és differenciálódása történik.

Úgy véljük tehát, hogy a mostani üzleti karrierre készülók értékrendszere, céljai, sikerkritériumai nem különböznek a most 30-as éveikben lévő, a 90-es években gyors karriert megvalósított korosztálytól.

- Fő karriercéljuk ugyanúgy az egzisztenciateremtés, értékrendszerükben az eszközorientáció a jellemzó, nagy szerepet kap az individualizmus, a fogyasztás, $a z$ anyagiasság, a versengés. A korosztály képét húen adja vissza a maguk által leggyakrabban választott tulajdonságok: anyagias, nyitott, elégedetlen, független, individualista, törtető, tudatos, tág érdeklődési körú, vállalkozó kedvú.

- Meghatározó a kívülról való irányítottság, a sikeresség kritériumai az anyagi jellegú, külsố összehasonlíthatóságra lehetôséget adó dimenziókban merülnek fel: lakás, autó, üdülés. Igényeiket és céljaikat a társadalom szúk felsố - bár nem legfelsố - rétegéhez igazítják.

- Ennek megfelelóen karrierértelmezésük klasszikus: (legalább közép-) vezetói pozíciót kívánnak elérni, mivel ez biztosítja az elvárt egzisztenciális igényeiket. Türelmetlenek, magas szintú célkitüzéseiket már rövid távon, a következô öt évben, a családalapításig meg kívánják valósítani.

- A közösség továbbra is elsôsorban a saját családot jelenti, ahogyan azt a Fiatal vezetô kutatásunkban is idéztük egy amerikai vizsgálatból: „nem azt remélik elsősorban, hogy pozitívan járulhatnak hozzá világuk formálásához, hanem abban reménykednek, hogy képesek lesznek egy biztonságos oázist találni abban a világban, amely szerintük rosszabb lesz, és amelyre - hitük szerint - nemigen lehetnek hatással." (Parks, 1994).

- A családon belül továbbra is erós a hagyományos szerepmegosztás, ahol a férfi az egzisztencia-teremtó és a nóknek szakmai karrierjüket az anyai szerepük alá illik rendelni.

- Továbbra is nagyon jellemző a karriertervezés olyan felfogása, miszerint az elsó évek - a munkaadó felé történó - áldozathozatal idôszaka, amit a késóbbiek-

\section{VEZETÉSTUDOMÁNY}

XXXVIII. ÉVF. 2007. 2. SZÁM 
ben a visszafogás, a személyes, családi célok magasabb prioritása követ.

A 20-as és a 30-as korosztályok közötti legfontosabb különbségeket a munkaerópiacon, az oktatási intézményrendszerben bekövetkezett változásokból lehet levezetni. Saját helyzetük értelmezésük szerint rosszabbodott, erôs versenyhelyzetben vannak. Azaz kevesebb a munkalehetőség, amelyre viszont a sok diplomázó miatt többen jelentkeznek. Ebból a versenyhelyzetból vezetik le megkülönböztető jegyeiket:

- Magasabbak a követelmények, ami már a felsófokú képzés alatt tudatos karrierépítést követel meg. Úgy kell kilépni a munkaerópiacra, hogy a diploma mellett több nyelvet is beszéljenek, legyen szakmai és külföldi tapasztalatuk. Ehhez jöhetnek hozzá az egyedi, további megkülönböztetést jelentő eredmények és tapasztalatok.

- Erôs jellemzójuik a felpörgetettség és a türelmetlenség, de végül is sokan már jó ideje dolgoznak, mire pályakezdőként elkezdenek dolgozni, és bizony többet is tanultak (nyelvek, külföld), mint az elóttuik járók. Türelmetlenségüket az is fokozhatja, hogy az elérni kívánt céljaik valóban nem túnnek irreálisnak, hiszen az elóttuik járó korosztály szerencsés helyzetének köszönhetôen többségében már fiatalon meg is valósíthatta óket. Csak hát változtak a körülmények. Nem szabad azonban abba a csapdába esnünk, mint a sokszor marketingízú, összemosó külföldi generációs tanulmányoknak, azaz egységes tömbként felfogni a korosztályt. A fenti, a többségre jellemző általános tulajdonságok ellenére az is kétségtelen, hogy az általunk vizsgált korosztály erôsen differenciált, nagyon szélsôséges minták élnek a következő kérdések megválaszolását illetően:

- Mit jelent nónek/anyának lenni? Megjelent a független, önmagáért (és gyerekéért) egzisztenciálisan is felelős nő képe, valamint létezik a karriert a családnál fontosabbnak tekintô nó útja is. (Még ha ez sokak, különösen a fiúk számára nem is elfogadható.)

- Mennyire tudatosan készülnek a karrierre? A versenyhelyzet nem feltétlenül a tudatosságot erôsíti. A karrierjüket mértanilag tervező, a jó pontokat tudatosan gyújtögetôk, vállalkozásukat akár már most megalapozók mellett ott vannak az iskola- és munkahelyválasztás során is sodródók, a környezeti bizonytalanságra személyes elbizonytalanodással választ adók is.

- Mennyire félnek/érzik magukat erôsnek? Bár a tudatosság, a törtetés, az önmaguk eladásának képessége fontos számukra, mégis jó pár olyan fiatallal is találkoztunk, akiben erôs félelem és bizonytalanság van jövőjét és lehetőségeit illetően.
- Mennyire érzékenyek a társadalmi kérdésekre? Bár a többség számára a közösség fogalma megáll a család, illetve a barátok szintjén, mégis vannak közöttük olyanok, akik számára a társadalmi felelősség, az értelemteli munka, a teljességre való törekvés alapvetô értékorientációkat jelentenek. A többség számára, úgy gondoljuk, ezek a témák csak ritkán múködnek valóban magatartásvezérlóként, inkább csak egyfajta vágyképek. Ám már ott vannak azok is, akiknél erősebb a hatásuk. A magukat kifejezetten a tehetségesnek tartók azok, akik elutasítanak bizonyos társadalmi szempontból nem pozitívnak ítélt iparágakat.

Mindezen tendenciákat lehet szomorúan és örömmel is olvasni. Nem áll szándékunkban mérleget vonni, illetve értékítéletet mondani. Egyetlen veszélyre hívjuk fel a figyelmet. Az értékalapúság hiányára, a belsô értékközpontok bizonytalanságára. Időnként az volt a benyomásunk, hogy erósen befolyásolható ez a korosztály. Kívülrôl meg lehet mondani nekik, hogy mi legyen a vágyuk (siker), és az mit is jelent. Még az is valahogy kívülról érkezik, hogy legyenek tudatosak. „Tudatosnak kell lenni, ezért az leszek”. Ez valahogy olyan furcsán hangzik.

Jól tetten érhető ez a kívülrôl származó belső motiváció. Amikor a munkába állásnál örömmel mondják, hogy mostantól felelős leszek valamiért, akkor azt gondoljuk igazából - az örömmel teljesített - külső megfelelés élményére gondolnak: „Ezt a feladatot is végre tudom majd hajtani, ügyes vagyok!" Valaki a beszélgetések során, egy rosszul megfogalmazott mellékmondatban az önmegvalósítást az elvárásoknak való megfeleléssel azonosította... Szerintünk nem véletlenül. A tanulmányt egy könnyednek ható idézettel zárjuk:

„, Kellett egy kis idó elfogadni azt, hogy mi a francnak van ez a cég. Miért jó nekem, hogy ezt csinálom, ebben semmi vagány dolog nincsen." (3)

A könnyed megfogalmazáson túl komoly dilemmát látunk a háttérben. Ha a korosztály döntő többsége valóban elsôsorban az egzisztenciateremtés érdekében, anyagi okokból dolgozik, és ez alapján kötődik a munkahelyéhez, akkor végül is egyik félnek sem érdemes túl sok tartalmi elemet beletenni ebbe a kapcsolatba. Ez egy sima üzletkötésnek túnik. (Te adsz idôt, energiát, én adok pénzt, státust.) Ebben az esetben az sem meglepó, ha mindegyik fél megpróbál minél többet kihúzni a másikból: a piaci jellegú, alkualapú tranzakcióknál ez már csak így van. Kérdés, hogy a mai munkahelyek valóban képesek-e, akarnak-e másfajta tartalmú (értékalapú) szerződést kínálni - túl a lózungok szintjén -, illetve a munkavállalókban is van-e igény a belsô motivációkon alapuló múködésmódra. Izgalmas lenne ennek a lehetőségnek a megismerése, megélése. 


\section{Melléklet}

A kitöltók, fókuszcsoporton résztvevốk jellemzôii:

\begin{tabular}{|c|c|}
\hline Demográfiai jellemzó & Mintabeli arány \\
\hline \multicolumn{2}{|l|}{ Nem } \\
\hline Nố & $53,9 \%$ \\
\hline Férfi & $46,1 \%$ \\
\hline \multicolumn{2}{|l|}{ Születési év } \\
\hline 1978 & $00,7 \%$ \\
\hline 1979 & $06,8 \%$ \\
\hline 1980 & $16,3 \%$ \\
\hline 1981 & $13,6 \%$ \\
\hline 1982 & $19,7 \%$ \\
\hline 1983 & $23,8 \%$ \\
\hline 1984 & $16,3 \%$ \\
\hline 1985 & $02,7 \%$ \\
\hline Válaszadók átlagos életkora & 24 év \\
\hline \multicolumn{2}{|c|}{ Végzett iskola típusa szerint } \\
\hline Egyetem & $66,9 \%$ \\
\hline Fớiskola & $33,1 \%$ \\
\hline \multicolumn{2}{|c|}{ Végzett kar szakmai jellege szerint } \\
\hline Gazdasági & $77,9 \%$ \\
\hline Bölcsész & $13,6 \%$ \\
\hline Múszaki & $04,5 \%$ \\
\hline $\begin{array}{l}\text { Előzóek kombinációja (pl. informatikai } \\
\text { közgazdász, múszaki menedzser) }\end{array}$ & $02,6 \%$ \\
\hline Egyéb & $01,3 \%$ \\
\hline
\end{tabular}

\section{Felhasznált irodalom}

Bokor A. - Radácsi L. (2006a): Fiatal vezetók életstratégiái - Vezetôvé válni, vezetônek lenni, Vezetéstudomány, XXXVII. Évf. 6. sz. 2-15. o.

Bokor A. - Radácsi L. (2006b): Aranykalitkában - Fiatal vezetốk életstratégiái a rendszerváltás után, Aliena kiadó, Budapest

Gattiker, U. E., Larwood, L. (1988): 'Predictors for Managers' Career Mobility, Success, and Satisfaction', Human Relations, 41 (8): 569-591.

Gattiker, U. E., Larwood, L. (1989): 'Career Success, Mobility and Extrinsic Satisfaction of Corporate Managers', The Social Science Journal, 26 (1): 75-92.

Grandjean, B. D. (1981): History and career in a bureaucratic labor market, American Journal of Sociology, 86 (5): 1057-1092.

Hudson (2005): The Generational Mirage? A pilot study into the perceptions of leadership by Generation, Hudson, Australia/New Zealand

Kaimal, G. (2003): Gen-X Meets Gen-Y Youth Perceptions and Concerns about the Future - A Review of the Literature, Foresight and Governance Project
Lancaster, Lynn \& Stillman, D. (2002): When Generations Collide. Haper Business.

Leonard, B. (2001): Most job hunting college grads listen to their parents. Human Resource Management, 46 (1)

Mannheim, K. (1928): The Problem of Generations. In Essays on the Sociology of Knowledge. Oxford University Press, 276-320.

Mayrhofer W. - H. Steyrer - M. Meyer - A. Iellatchitch - A. Hermann - G. Strunk - C. Erten - C. Mattl - M. Schiffinger - A. Dunkel (2006): Towards a habitus based concept of managerial careers, Conference paper: Managerial Careers in a Post Industrial Context, Toronto

Nancy Pekala (2001): Conquering the generational divide, Journal of Property Management, november-december, 30-38. o.

Northwest Regional Educational Laboratory (2005): Generation Y, 2003-2004 Evaluation Data, Generation YES

Parks, S. D. (1994): Túl késô? A szakmai etika kialakítása és a fiatalok. Budapest: BKE Gazdaságetikai Központ, 39-102.)

Riccucci, Norma. (2002): Managing Diversity in Public Sector Workforces. USA: Westview Press.

Rose, N. (1989): Governing the Soul: The Shaping of the Private Self, Routledge, London.

Ruiz Gina (2006): What Young Graduates Want, Workforce Management Online, April 2006

Tulgan, Bruce. (2000): Managing Generation X. NY: Norton and Co.;

\section{Lábjegyzet}

${ }^{1}$ Jelen publikáció alapját a csapatmunkában elvégzett kutatás jelenti, ezért is maradtam a többes szám elsô személyú fogalmazásnál a legtöbb esetben. Az egyes fázisokban - fókuszcsoport moderálás, tartalomelemzési kódolás, statisztikai háttérelemzés - többen is hozzájárultak a végsô eredményekhez: Frisch Anita, Fertetics Mandy, Ladányi Viktória, Dr. Radácsi László, Szilas Roland. Köszönöm a lektorok észrevételeit, javaslatait. A cikk természetesen a szerzố nézeteit tükrözi.

2 A kutatás támogatásáért köszönetünket fejezzük ki a kutatást támogató szervezeteknek: Szervezési és Vezetési Tudományos Társaság, AVON, Állami Autópálya Kezelő, B.A.T, BNP-Paribas, CIB Bank, E.on, Ernst \& Young, FCI Connect, IBM, K\&H Bank, Magyar Nemzeti Bank, Magyar Telekom, MOL, Philip Morris, Procter \& Gamble, TetraPak, valamint az empirikus kutatás megszervezésében közremúködő tanároknak, diákszervezeti vezetóknek és HR-vezetóknek

3 Az utóbbiak elnevezése még nem egyértelmú, egyes publikációkban „The Net Generation”, „Millennials”, „Echo Boomers”, „iGeneration”, „Second Baby Boom”, vagy „Google generation” megnevezéssel is illetik óket. Mi a továbbiakban az Y-generáció megnevezést használjuk.

4 Utalunk azonban arra, hogy a Fiatal Vezetô Kutatásban is kiemelkedő család-, és főleg gyerekorientáltsággal találkoztunk, legalábbis a vallott értékek szintjén. Azonban mélyinterjúk alaposabb elemzése azt mutatta, hogy a gyerekek emlegetése nagyon sokszor inkább csak egyfajta pajzsként, hárító mechanizmusként, illetve önerósítésként szolgált. (Bokor-Radácsi 2006b)

5 Bokor és Radácsi (2006a), Bokor és Radácsi (2006b) 